OECD Regional Development Working Papers 2014/10

Income Inequality, Urban Size and Economic Growth in OECD Regions

\section{Vicente Royuela,}

Paolo Veneri, Raul Ramos 


\section{OECD REGIONAL DEVELOPMENT WORKING PAPERS}

This series is designed to make available to a wider readership selected studies on regional development issues prepared for use within the OECD. Authorship is usually collective, but principal authors are named. The papers are generally available only in their original language English or French with a summary in the other if available.

OECD Working Papers should not be reported as representing the official views of the OECD or of its member countries. The opinions expressed and arguments employed are those of the author(s).

This document has been produced with the financial assistance of the European Union. The views expressed herein can in no way be taken to reflect the official opinion of the European Union.

Working Papers describe preliminary results or research in progress by the author(s) and are published to stimulate discussion on a broad range of issues on which the OECD works. Comments on Working Papers are welcomed, and may be sent to either gov.contact@oecd.org or the Public Governance and Territorial Development Directorate, OECD, 2 rue André-Pascal, 75775 Paris Cedex 16, France.

Authorised for publication by Rolf Alter, Director, Public Governance and Territorial Development Directorate, OECD.

OECD Regional Development Working Papers are published on http://www.oecd.org/gov/regional/workingpapers

Applications for permission to reproduce or translate all or part of this material should be made to: OECD Publishing, rights@oecd.org or by fax 33145249930.

(C) OECD 2014 


\title{
INCOME INEQUALITY, URBAN SIZE AND ECONOMIC GROWTH IN OECD REGIONS
}

\author{
Vicente Royuela*, Paolo Veneri`\& Raul Ramos` \\ OECD, Regional Development Policy Division
}

\begin{abstract}
The purpose of this paper is to understand how income inequality is associated with economic growth in OECD regions and whether the degree and type of urban concentration affects this relationship. Both income inequality and urban concentration can be seen as patterns of resource allocation that are particularly interlinked at the regional level. We combine household survey data and macroeconomic databases, covering a period ranging from 2004 to 2012 for comparable regions in 15 OECD countries. Econometric results show that, at least for the short period under consideration, there is a general negative association between inequalities and economic growth, especially since the start of the economic crisis. This relationship is sensitive to the type of urban structure. Higher inequalities seem to be more detrimental for growth in large cities, while regions characterised by small cities and rural areas are less affected. ${ }^{1}$
\end{abstract}

JEL classification: R11, R12, 015 .

Keywords: Inequality, economic growth, urban, OECD regions.

- Grup d'Anàlisi Quantitativa Regional (AQR-IREA), University of Barcelona. E-mail: vroyuela@ub.edu

- Regional Development Policy Division, Public Governance and Territorial Development, OECD, Paris. Email: paolo.veneri@oecd.org.

• Grup d'Anàlisi Quantitativa Regional (AQR-IREA), University of Barcelona. E-mail: rramos@ub.edu

1. This paper uses authors' estimates of income distribution based on data provide by national institutes of statistics. Indicators are based on a number of household surveys (the Eurostat's 2004-2012 European Survey on Income and Living Conditions -EU-SILC - for most European countries; the Encuesta de Caracterización Socioeconómica Nacional - CASEN - for Chile; the Encuesta Nacional de Ingreso y Gastos de los Hogares (ENIGH) for Mexico; the Current Population Survey (CPS) for the United States; the Survey of Labour and Income Dynamics (SLID) for Canada; and the Korean Labour \& Income Panel Study (KLIPS) for Korea. Authors used the OECD Income Distribution Database when data were not publicly available. Errors in the interpretation of the data or in the calculations from micro-data, and the responsibility for all conclusions drawn from the data lie entirely with the authors.

This work was undertaken in the context of the OECD project "How's life in your region: Measuring regional and local well-being for policy making" carried out by the OECD Public Governance and Territorial Development under the guidance of the Working Party on Territorial Indicators (WPTI). WPTI Delegates are kindly acknowledged for their comments. 
TABLE OF CONTENTS

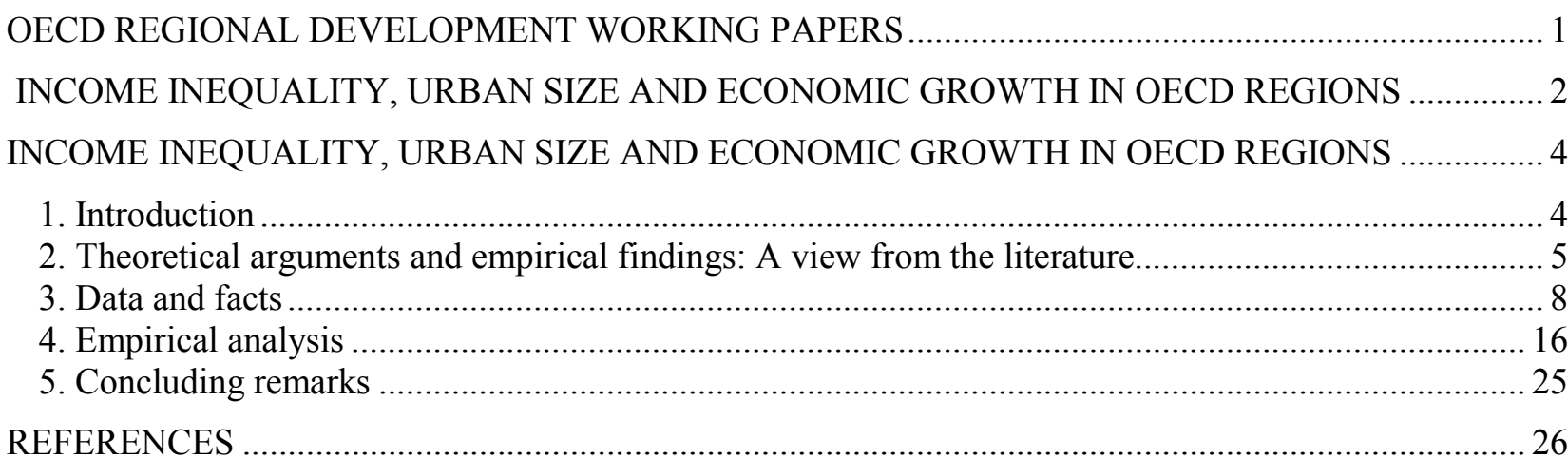

\section{Tables}

Table 1. Mechanisms underlying the relationship between income inequality and economic growth ....... 6

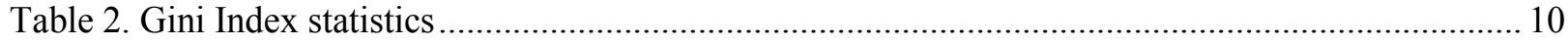

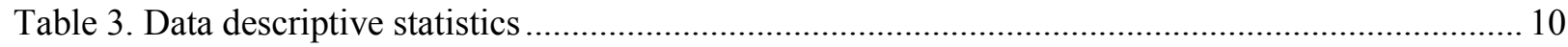

Table 4. Correlation coefficients between GDP and GDP per capita growth and inequality ................... 13

Table 5. Correlation between inequality and urbanisation rates ....................................................... 15

Table 6. Inequality and economic growth measures by urban size, OECD regions (2004-2012)............ 16

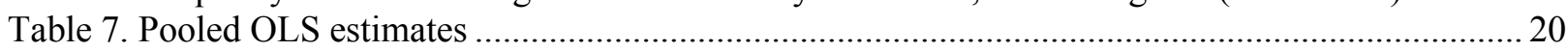

Table 8. Between, random, fixed effects and instrumental variables estimations of models for the Gini Index. 21

Table 9. Estimations of models for the Gini Index interacted with urban size ......................................... 22

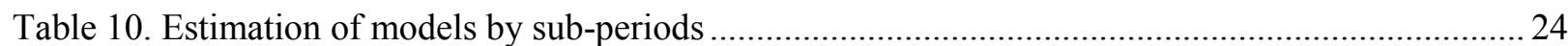

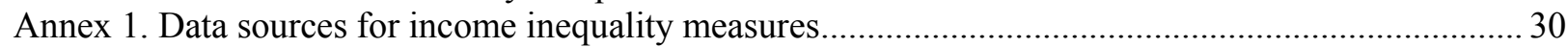

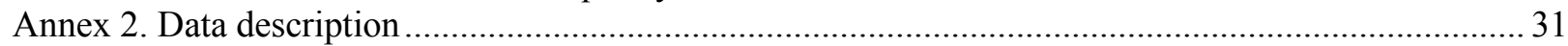

\section{Figures}

Figure 1: Indicators of inequality within OECD regions: Distributional changes over time (2004-2012)11 Figure 2. Change over time of income inequality within OECD regions (2004-2012) ......................... 12 Figure 3. Inequality (Gini Index) and GDP per capita growth: Cross-sectional and time components,

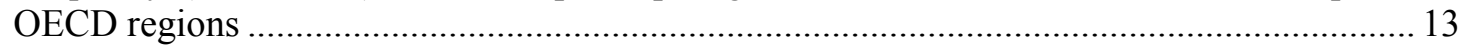

Figure 4. Income inequality and growth of GDP per capita: Pre- and post-crisis................................. 14

Figure 5. Income inequality by urban size, OECD regions (2004-2012) …........................................ 15

Annex 3. Inequality and GDP per capita growth rates, according to different indicators of inequality ... 32 


\section{INCOME INEQUALITY, URBAN SIZE AND ECONOMIC GROWTH IN OECD REGIONS}

\section{Introduction}

Since the start of the economic crisis of the late 2000s, increasing concerns have emerged in most developed countries on the distributional effect of the crisis and on those of the recovery. In most OECD countries, the gap between rich and poor has widened and growth in GDP per capita has not fully trickled down to household incomes (OECD, 2011). Several authors have emphasised the role of the current crisis on the increasing inequality (Krugman, 2008; Stiglitz, 2009; Brescia, 2010; Rajan, 2010; OECD, 2014a). Such an increase can have economic implications, since growth does not automatically benefit all sectors of society. Recent evidence shows that income inequality, especially when driven by the gap between lowincome earners and the rest of the population, is associated with lower social mobility through lower investment in human capital (Cingano, 2014). Others distinguish between equality of opportunities and equality of outcomes as two parallel and differentiated components of inequality (World Bank, 2006), or between structural and market inequality (Easterly, 2007), with the latter having an expected positive effect on economic growth.

Understanding how inequality affects economic growth has been attracting growing interest by both scholars and policy makers. Notwithstanding a vast theoretical and empirical literature on this topic, results are still inconclusive. The literature has analysed different transmission channels of inequality on economic growth, some of them negative (socio-political instability, political economy issues, creditmarket imperfections, market size and fertility) and others positive (higher aggregate savings, investment indivisibilities and incentives promotion) (Neves and Silva, 2014). Empirically, differences in estimation methods, length of the time horizon, data quality and sample coverage substantially affect the magnitude of the estimated effect of income inequality on economic growth (De Dominicis et al., 2008).

The goal of achieving economic growth that benefits the largest possible number of people has been made increasingly explicit in recent years. This is reflected, for example, in the European Union's 2020 Strategy or by the Inclusive Growth Initiative of the OECD (OECD/The World Bank, 2012). Achieving inclusive growth also requires the benefits of development to be shared across all regions. Material conditions and quality of life can be remarkably different across space while, at the same time, local conditions can affect individual opportunities, especially for young people. Recent OECD work has provided evidence of large disparities in socio-economic conditions across regions, highlighting that regions do not simultaneously enjoy high or low performance in all well-being dimensions in any country (OECD, 2014b). Thus, developing metrics of inequalities at sub-national level and advancing the understanding of the role of inequalities for regional economic growth can be useful in designing more effective policies to improve individuals' well-being.

There are several reasons why considering the inequality-growth relationship at regional or subnational level is relevant. First, empirical analyses at regional level can reduce the bias due to omitted variables and mitigate issues of incomparability across countries by focusing on smaller spatial entities, which better reflect the actual conditions where people live. The use of regional data also helps to magnify how small disparities in initial conditions affect economic growth (Partridge, 2005) and it allows to better account for the patterns of urban agglomeration. Such patterns are certainly linked to inequalities through, among others, mechanisms of sorting of the most talented individuals, selection of the most productive firms and agglomeration advantages taking place in cities (Behrens et al., 2014). Finally, the mechanisms underlying the link between inequality and economic growth as well as the possible policy options can have a different relevance at the regional scale than at the national one. For example, income redistributive 
taxes are for a large part defined at the national level (political economy channel), while other factors connected with living conditions (e.g. crime) are likely to be more important at the local level. Both aspects can affect inequality as well as economic performance, but they are not likely to play the same role at the national level as they do at the regional level.

The purpose of this paper is to provide new empirical evidence on the relationship between income inequalities and economic growth in OECD regions. The analysis is carried out on a panel of comparable regions from 15 different OECD countries covering three continents over the period between 2004 and 2012. To our knowledge, only a few other works have tried to understand such a relationship at the regional scale, in large part because of data constraints. Most of these works refer to regions within a single country, especially the United States (Fallah and Partridge, 2007; Frank, 2009; Janikas and Rey, 2008; Panizza, 2002; Partridge, 1997, 2005, 2006), although some analyses were done for a set of European regions (Ezcurra, 2010; Perugini and Martino, 2008; Rodríguez-Pose and Tselios, 2010; Rooth and Stenberg, 2012).

This paper also focuses on the role of urbanisation as a potential transmission channel of inequality on economic growth, by using a consistent economic definition of cities applied to the countries under analysis. The use of such a definition of cities is another novel aspect of this study; it helps identify the extent of urbanisation within regions while at the same time limiting the bias introduced by different administrative definitions across countries. The main findings show that inequality and economic growth are negatively associated, especially when differences between continents are accounted for. This negative relationship has been particularly evident since the start of the economic crisis, suggesting that more inclusive societies might help regional resilience to economic shocks. Moreover, we found that the link between inequality and growth is affected by urban size. Inequalities are, on average, higher in larger cities. And, for the period under analysis, the negative link between inequality and growth becomes larger in magnitude with city size.

Section 2 provides the rationale for analysing the relationship between inequality and growth at the sub-national level. It also reviews, drawing from the existing literature, the mechanisms through which inequality can affect economic growth. Section 3 presents the empirical model and the data description, while section 4 presents the main results. Finally, section 5 provides some concluding remarks.

\section{Theoretical arguments and empirical findings: A view from the literature}

The way that inequality may affect economic growth has attracted much attention in academic research. Comprehensive overviews of theories and empirical evidence on such a relationship are provided by Ehrhart (2009) and Galor (2009), while a more recent critical survey of the empirical works is provided by Neves and Silva (2014). The bulk of this literature is devoted to an analysis of the inequality-growth relationship at the national level, but only a few studies have tried to understand such a relationship at the regional or, more generally, sub-national level. However, there are specific reasons why a regional perspective is relevant. First, what individuals perceive and how they behave as citizens and economic agents are likely to be affected, at least partially, by local conditions. The socio-economic characteristics of the place and of the communities where individuals actually live can have an important role in shaping the opportunities available and the incentives for individuals and firms to take decisions yielding different economic outcomes. Investment in human capital, for example, can be shaped by different local conditions, including life expectancy (Rodríguez-Pose and Tselios, 2010), which in turn can be very different across regions and groups of people. For example, the difference between the best and the worst performing OECD region in terms of life expectancy is 15 years, more than double that among countries. Within the United States, such a difference is six years (OECD, 2014b). 
Regarding the main mechanisms underlying the relationship between inequality and economic growth with a specific regional focus, it is worth acknowledging that no general theory - nor empirical evidence exist that identify a stable and clear relationship between inequality and growth. Recent evidence at the national level shows that while in the short run a positive relationship predominates, in the long run the reverse is observed (Halter et al., 2014). Table 1 summarises several arguments that have been put forth to uncover the mechanisms underlying such a complex relationship. Some of these mechanisms act as growth-enhancing factors, while others act as growth-hindering ones.

Table 1. Mechanisms underlying the relationship between income inequality and economic growth

\begin{tabular}{|c|c|}
\hline Inequality as a growth-enhancing factor & Inequality as a growth-hindering factor \\
\hline \multicolumn{2}{|c|}{ Accumulation of physical and human capital } \\
\hline $\begin{array}{l}\text { Higher physical capital investment (rich people have } \\
\text { higher saving rates) (Barro, 2000; Dynan et al., 2004; } \\
\text { Kaldor, 1957) }\end{array}$ & $\begin{array}{l}\text { Lower human capital accumulation, under credit } \\
\text { market imperfections (Bénabou, 2002; Galor and } \\
\text { Zeira, 1993; Easterly, 2001) }\end{array}$ \\
\hline \multicolumn{2}{|c|}{ Economic incentives } \\
\hline $\begin{array}{l}\text { Higher incentives for competition and risk taking } \\
\text { (Rebelo, 1991; Voitchovsky, 2005) }\end{array}$ & Lower incentives to borrow (Aghion et al., 1999a) \\
\hline \multicolumn{2}{|c|}{ Political economy arguments } \\
\hline $\begin{array}{l}\text { Higher wealth can induce less effort in the presence } \\
\text { of market imperfections due to moral hazard } \\
\text { (Aghion et al., 1999a) } \\
\text { Higher taxes allow investment in public education } \\
\text { and health (Aghion and Bolton, 1990; Saint-Paul and } \\
\text { Verdier, 1993) }\end{array}$ & $\begin{array}{l}\text { Voters opt for higher taxation and redistribution, } \\
\text { decreasing incentives to invest and reducing growth } \\
\text { (Alesina and Rodrik, 1994; Persson and Tabellini, } \\
\text { 1994) }\end{array}$ \\
\hline \multicolumn{2}{|c|}{ Political and macroeconomic instability } \\
\hline & $\begin{array}{l}\text { Higher political instability creates uncertainty and } \\
\text { reduces investment, hindering economic growth } \\
\text { (Alesina and Perotti, 1996) }\end{array}$ \\
\hline \multicolumn{2}{|c|}{ Demand-side dynamics } \\
\hline $\begin{array}{l}\text { Dynamic price effect (higher income people may be } \\
\text { more willing to pay for new goods, stimulating } \\
\text { investment and innovation) (Bertola et al., 2006) }\end{array}$ & $\begin{array}{l}\text { Market size effect (fewer consumers can afford to buy } \\
\text { new goods) (Bertola et al., 2006) }\end{array}$ \\
\hline
\end{tabular}

Accumulation of physical and human capital. Two different theoretical traditions provide conflicting views on the direction of the inequality-growth relationship, based on the role it gives to physical and human capital accumulation in the process of development. These two approaches might be called the classical approach and the modern paradigm, respectively (Galor, 2000).

The classical approach suggests that saving rates increase with wealth and that wealthier people have a higher marginal propensity to save (Kaldor, 1957; Dynan et al., 2004). This implies that in a system where resources are more concentrated among individuals, aggregate investment in physical capital will be relatively higher, fostering economic growth (Barro, 2000). 
The modern paradigm, on the other hand, focuses on the role of human capital accumulation rather than on investment in physical capital, the former being the major driver of growth in developed economies (Galor and Moav, 2004). The increased importance of human capital accumulation in later stages of development reverses the link between inequality and growth. As human capital is by definition embedded in individuals, its whole stock will be larger if more people invest in its accumulation. More equal societies give people greater opportunities to invest in human capital because of imperfections in the financial and credit markets that prevent worse-off individuals from carrying out such costly investments (Galor and Zeira, 1993; Bénabou, 2002). In this view, more equal societies can be seen as opportunity-enhancing ones, given the decreasing returns of investment in education at the individual level and the fact that households' wealth is a major determinant of such investments. Recent empirical analyses at the national level further support the idea that the negative relationship between inequality and growth might be driven by obstacles to human capital accumulation (Cingano, 2014). Other evidence from developed countries shows that increases in income inequality are negatively associated with intergenerational earning mobility, which in turn yields greater polarisation in educational and health outcomes (Causa and Johansson, 2009). In addition, higher income inequalities were found to slow skill development among individuals whose parents come from a poorer background, while they did not affect that of individuals with a richer background (OECD, 2014a). These findings suggest that inequality is more likely to harm economic growth when such inequality is driven by the lower part of the distribution, meaning that the lower and middle classes lag behind and lose opportunities (Cingano, 2014).

Compared with countries, regions are much more open economies. Capital and labour - particularly a highly educated workforce - can move across regions at a lower cost and tend to move to places where they can enjoy higher returns. Cities and metropolitan areas certainly have an advantage in attracting capital and labour, thanks to more efficient provision of public services (due to economies of scale) and agglomeration economies. In principle, perfectly mobile production factors should yield, in equilibrium, an optimal allocation of resources with no spatial inequalities. However, even in the presence of perfect factor mobility, differences in initial factor endowments, sectoral specialisation and agglomerations externalities can actually widen inter-regional disparities (Rice and Venables, 2003). More specifically, an initial higher specialisation in sectors requiring more high-skilled workers can attract further high-skilled labour and increase the gap in earnings. As a result, it may turn out that factor mobility increases income inequalities in relatively rich regions, while reducing those in worse-off ones (Perugini and Martino, 2008). This might determine the co-existence of a positive relationship between inequality and growth at regional level with a negative relationship at the country level (Fallah and Partridge, 2007).

Economic incentives. A common hypothesis among economists is that inequalities are growthenhancing by encouraging competition and investment. Societies where ability is rewarded stimulate individual effort, productivity and risk taking (Voitchovsky, 2005: 276). These economic incentives can also affect the accumulation of human capital and the effort to seize the returns of skills. However, while positive incentives can work along the whole income distribution, those for workers with very low wages can be counterbalanced by feelings of unfairness (Akerlof and Yellen, 1990). Borrowers may also tend to invest less effort if such effort is unobservable (Aghion et al., 1999a). As above, these incentives may be larger in large cities, which enjoy agglomeration economies and where the most talented individuals tend to sort (Behrens et al., 2014).

Political economy. Inequalities might negatively affect economic growth through an effect on taxation. This idea was put forward by Persson and Tabellini (1994) and Alesina and Rodrik (1994), who argued that in relatively more unequal societies, people would vote for higher taxation and redistribution. Higher taxation has a negative effect on the incentives to invest, which, in turn, negatively affects economic growth. This idea is supported by the negative correlation often found in cross-sectional regressions at the country level between initial income inequality and subsequent economic growth. 
However, the political economy argument under which higher redistribution generates lower growth is not fully supported by empirical evidence. Aghion et al. (1999a) demonstrated that in the presence of ex-ante moral hazard and imperfections in the credit market, greater inequality reduces aggregate incentives to wealth accumulation, since individuals' efforts decrease their wealth. Political economy arguments are expected to be much less important when focusing on regions, given the weaker tax-redistribution mechanisms usually available at sub-national level (Partridge, 1997; Panizza, 2002). On the contrary, social expenses and public services are usually provided locally. If this redistributive channel were applied favouring education and the accumulation of human capital, a positive impact on long-run growth could be expected (Aghion and Bolton, 1990; Saint-Paul and Verdier, 1993).

Political and macroeconomic instability. Another channel through which inequalities can affect economic growth is political instability. Alesina and Perotti (1996) provided cross-country evidence that income inequalities, through the generation of social discontent, generate higher political instability, which in turn yields lower investment and hence lower economic growth. Macroeconomic instability can be generated by inequalities in the access to investments, under the hypothesis of credit-market imperfections. The idea is that higher inequality might imply that only a small fraction of the population has the possibility to invest (Aghion et al., 1999b). At the regional level, this channel would play a role through higher crime rates rather than institutional instability.

Demand-side dynamics. On the demand side and in the short run, the link between inequalities and growth depends on the balance between two different effects: the market size and the dynamic price effect. The idea is that, in a short time horizon, innovation is affected by the demand for new products. The latter require innovation, which in turn drives economic growth. In a more equal society, more individuals will be able to buy a new product, hence stimulating innovation by firms and generating economic growth. However, the richest individuals have a higher willingness to pay for new goods and the higher price that can be applied by monopolistic producers can stimulate further innovation and growth (Bertola et al., 2006).

\section{Data and facts}

\section{Income inequality within regions}

Our data set includes 214 TL2 regions ${ }^{2}$ from 15 OECD countries, of which ten are European (Belgium, Czech Republic, Estonia, Finland, France, Greece, Italy, Luxemburg, Spain and the United Kingdom), four American (Canada, Chile, Mexico and the United States) and one Asian (South Korea). Indicators of inequality at regional level were computed using micro-data from household income surveys publicly available or made available through the OECD Income Distribution Database, following the method applied by Piacentini (2014). Details on the data sources are provided in Annex 1. For reasons of robustness, inequalities within regions were computed using several indicators related to equivalised household annual disposable income: the Gini Index, the top-bottom quintile ratio ( $p 80-20)$, the top-bottom decile ratio (p90-10), the bottom decile ratio (p50-10), the top decile ratio (p90-50), and the relative poverty rate using two alternative poverty lines, at $40 \%$ and at $60 \%$ of the median income. In general, our analysis uses the 2004-2012 income reference period. In particular, we have selected four time points: 2004, 2007, 2010 and 2012, with some adjustments due to data availability in the case of Chile and Mexico. For two countries, Korea and the United Kingdom, it was not possible to cover all the time points, but only three and two, respectively. Lastly, we used three-year averages of inequality measures for the

\footnotetext{
${ }^{2}$ TL2 regions are the higher level of OECD regions, which correspond in most cases to the principal sub-national unit of government (states or provinces).
} 
United States in order to increase the precision of the estimates due to relatively small sample sizes at the state level from the Current Population Survey.

A set of control variables was included to account for socio-economic and institutional factors that can have a role for regional economic growth. These factors include the degree and type of urban concentration, demographic (e.g. age structure) and institutional/cultural characteristics (religion, as in Rodríguez-Pose and Tselios, 2010 and Rodríguez-Pose, 2013), education, the sectoral composition of the economy and labour market characteristics. Definitions and sources for all of the variables can be found in Annex 2. Urban concentration was measured through the share of regional population living in cities, accounting for the size of the latter. More specifically, three classes of urban size were considered: less than 500,000 inhabitants, between 500,000 and 1.5 million inhabitants and beyond 1.5 million. Urban boundaries and population were identified according to the OECD definition of functional urban areas (FUAs) which are consistently identified in 29 OECD countries on the basis of population density and commuting flows (OECD, 2012).

On the whole, no dramatic changes in income inequality within regions occurred between 2004 and 2012. Figures 1 and 2 show the main trends of regional inequality in the 15 OECD countries considered. None of the indicators display a strong variation, as most of the points are close to the bisector of the plot, which represents the status quo over time. Thus, over the last years, both increasing and decreasing inequality are observed within regions, an aspect that is confirmed by the evolution of the Gini Index reported in Table 2. Nevertheless, a slightly decreasing trend can be observed until 2010, which then started increasing during the Great Recession. Table 3 summarises the basic statistics of the income distribution indicators and of the other variables considered in the remainder of this analysis. The variability of each indicator was broken down into between and within the standard deviation, reflecting the variation between regions and over time, respectively. Given the short period under consideration, most of the variation in inequality measures is due to cross-sectional differences, being the variation in time much smaller. This result is similar to other variables, with the exception of the ones the most affected by the business cycle, such as the unemployment rate or the relative share of the construction sector in terms of gross value added. 
Table 2. Gini Index statistics

\begin{tabular}{|c|c|c|c|c|c|}
\hline Year & Observations & Mean & Standard deviation & Minimum & Maximum \\
\hline 2004 & 196 & 0.364 & 0.075 & 0.217 & 0.546 \\
\hline 2007 & 197 & 0.359 & 0.078 & 0.214 & 0.523 \\
\hline 2010 & 209 & 0.355 & 0.068 & 0.227 & 0.529 \\
\hline 2012 & 203 & 0.359 & 0.070 & 0.224 & 0.513 \\
\hline
\end{tabular}

Source: Authors' elaboration based on national income household surveys.

Table 3. Data descriptive statistics

\begin{tabular}{|c|c|c|c|c|c|c|c|}
\hline & \multirow[b]{2}{*}{ Mean } & \multicolumn{3}{|c|}{ Standard deviation } & \multirow[b]{2}{*}{ Minimum } & \multirow[b]{2}{*}{ Maximum } & \multirow{2}{*}{$\begin{array}{l}\text { Number of } \\
\text { regions }\end{array}$} \\
\hline & & Overall & Between & Within & & & \\
\hline Total population & $3,551,698$ & $4,292,552$ & $4,289,136$ & 317,815 & 25,392 & $38,041,430$ & 214 \\
\hline GDP per capita (in scale) & 10.146 & 0.543 & 0.569 & 0.099 & 8.274 & 11.957 & 214 \\
\hline Two-year GDP growth rate & 0.021 & 0.035 & 0.018 & 0.031 & -0.179 & 0.206 & 214 \\
\hline $\begin{array}{l}\text { Two-year GDP per capita } \\
\text { growth rate }\end{array}$ & 0.012 & 0.035 & 0.017 & 0.030 & -0.189 & 0.187 & 214 \\
\hline Gini Index & 0.359 & 0.073 & 0.070 & 0.018 & 0.214 & 0.546 & 209 \\
\hline p80-20 & 3.026 & 0.778 & 0.748 & 0.202 & 1.798 & 7.461 & 209 \\
\hline p90-10 & 5.815 & 2.342 & 2.253 & 0.605 & 2.587 & 20.819 & 209 \\
\hline p90-50 & 2.252 & 0.444 & 0.414 & 0.149 & 1.571 & 4.128 & 209 \\
\hline p50-10 & 2.521 & 0.683 & 0.654 & 0.197 & 1.483 & 6.658 & 209 \\
\hline pov40 & 0.092 & 0.049 & 0.047 & 0.014 & 0.000 & 0.266 & 209 \\
\hline pov60 & 0.209 & 0.057 & 0.053 & 0.018 & 0.073 & 0.361 & 209 \\
\hline Urbanisation & 0.579 & 0.212 & 0.212 & 0.015 & 0.076 & 1.163 & 203 \\
\hline Religion diversity & 1.530 & 0.376 & 0.367 & 0.084 & 1.062 & 2.948 & 214 \\
\hline Agriculture share & 0.032 & 0.030 & 0.029 & 0.008 & 0.000 & 0.260 & 198 \\
\hline Industry share & 0.203 & 0.104 & 0.103 & 0.022 & 0.015 & 0.871 & 199 \\
\hline Construction share & 0.068 & 0.027 & 0.025 & 0.011 & 0.009 & 0.177 & 199 \\
\hline Education share in lower levels & 31.46 & 18.47 & 18.34 & 3.93 & 2.86 & 82.54 & 211 \\
\hline $\begin{array}{l}\text { Education share in average } \\
\text { levels }\end{array}$ & 44.84 & 17.41 & 17.21 & 2.66 & 7.16 & 82.71 & 211 \\
\hline Education share in high levels & 23.15 & 7.81 & 7.17 & 3.00 & 6.9 & 54.11 & 211 \\
\hline Elderly rate & 20.12 & 7.76 & 7.66 & 1.31 & 3.55 & 43.93 & 214 \\
\hline Unemployment rate & 7.51 & 4.86 & 4.04 & 2.70 & 0.24 & 38.55 & 214 \\
\hline Voters & 66.91 & 13.62 & 12.39 & 5.31 & 31.00 & 94.00 & 214 \\
\hline $\begin{array}{l}\text { Murder rate (homicides per } \\
100000 \text { inhabitants) }\end{array}$ & 50.84 & 83.63 & 62.33 & 50.93 & 0.00 & $1,214.16$ & 214 \\
\hline
\end{tabular}

Source: Authors' elaboration based on national household income surveys, various years. Sources and definitions of the variables are displayed in Annex 2. 

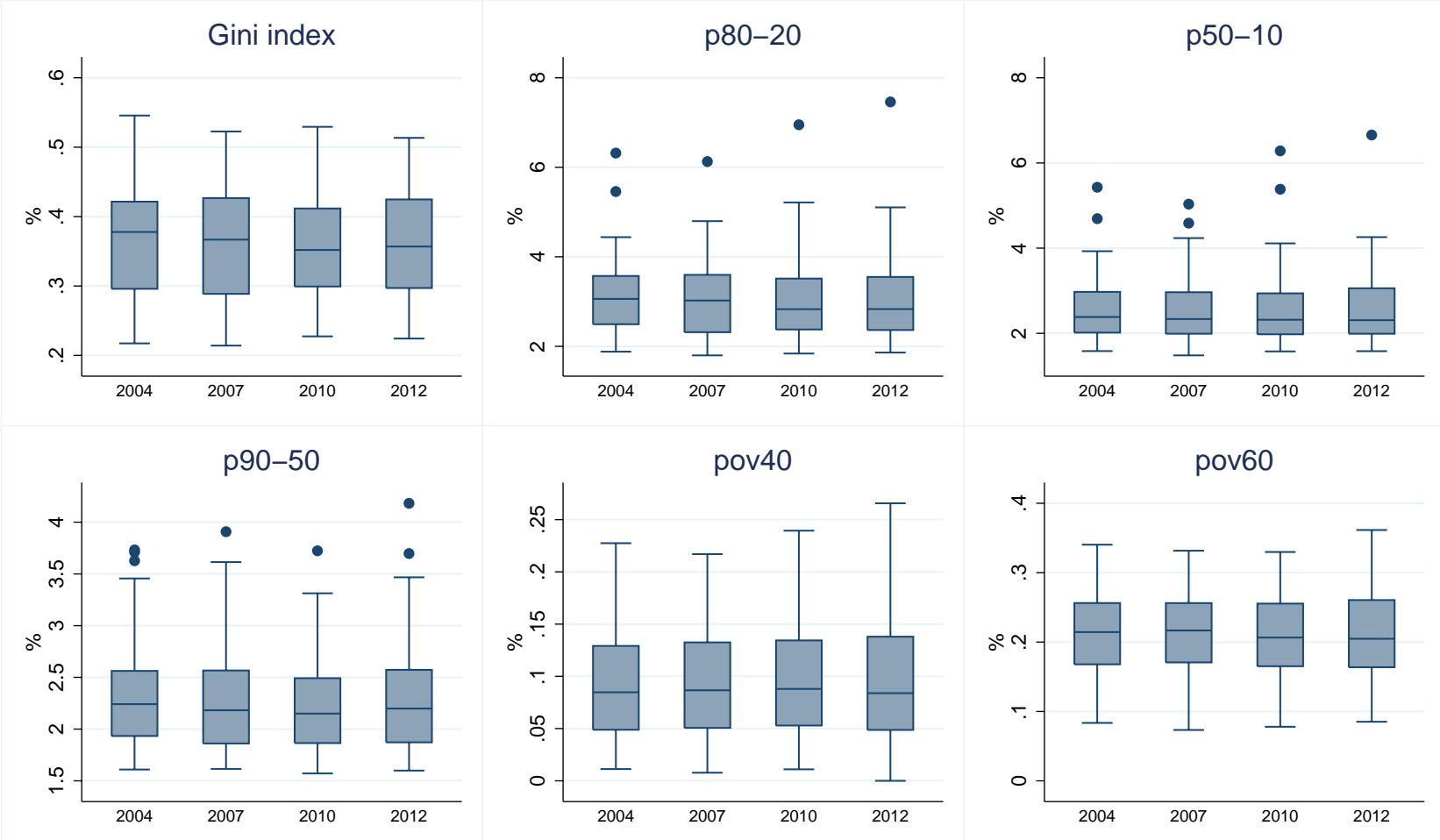

Source: Authors' elaboration based on national household income surveys, various years.

\section{Inequality and economic growth}

The strong decline in economic growth rates subsequent to the Great Recession has been heterogeneous across regions and countries (OECD, 2013). In order to provide a first overall picture on how regions with higher or lower levels of inequality have experienced higher or lower economic growth rates, Figure 3 plots the relationships between a measure of income inequality (Gini Index) and the twoyear growth rate of GDP per capita in constant PPP dollars (Annex 3 displays the same relationship by using the remaining inequality indicators). Figure 3 represents this relationship from three different angles: using raw data (left panel); considering every region's mean (middle panel), which highlights crosssectional variation; and, finally, considering region demeaned data (right panel), which only reports variations in time. While the time dimension does not reveal particularly striking patterns, the crosssectional variation suggests either an inverse U-shaped pattern or a bi-modal one. 
Figure 2. Change over time of income inequality within OECD regions (2004-2012)

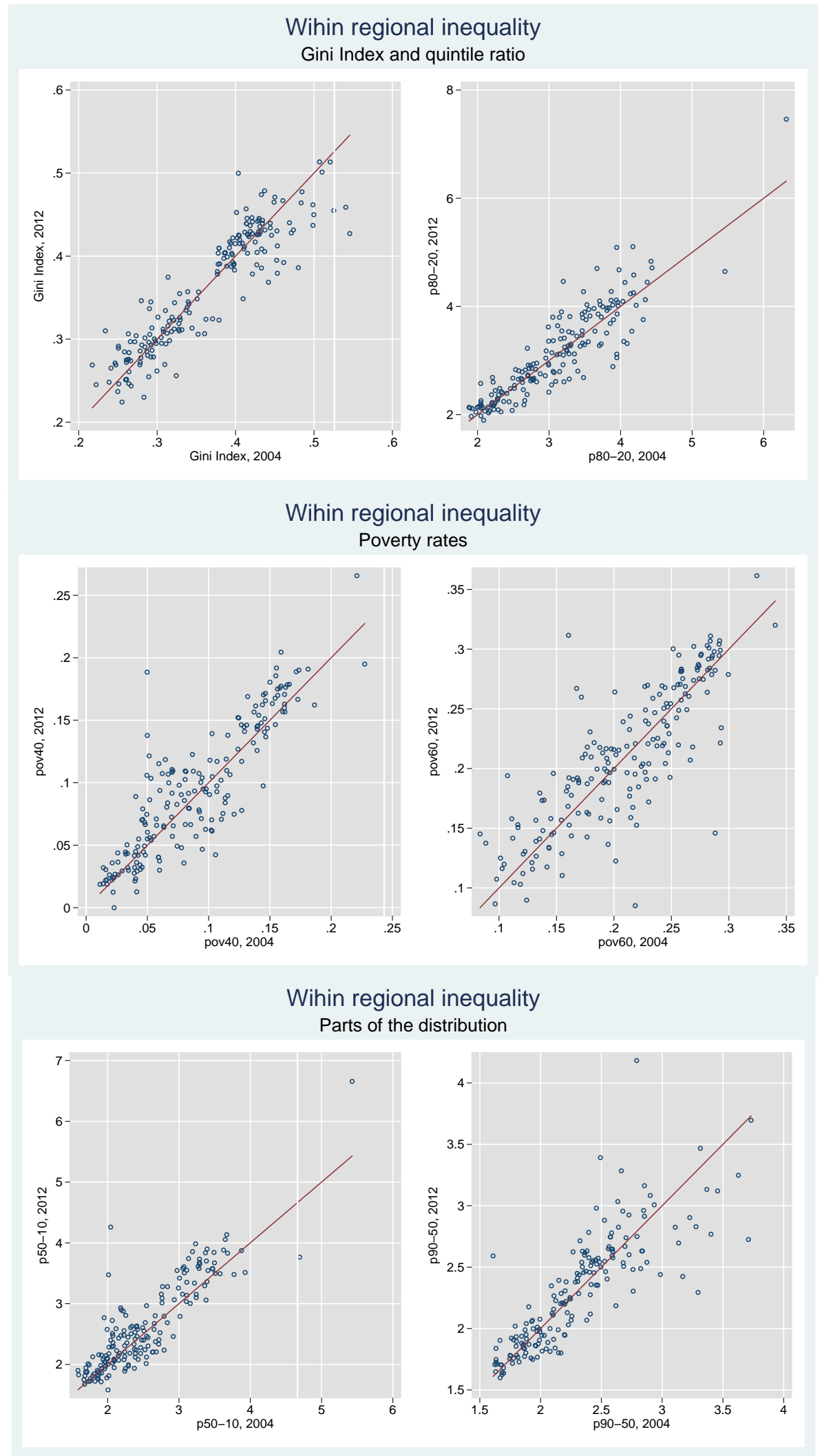

Source: Authors' elaboration based on national household income surveys, various years. 

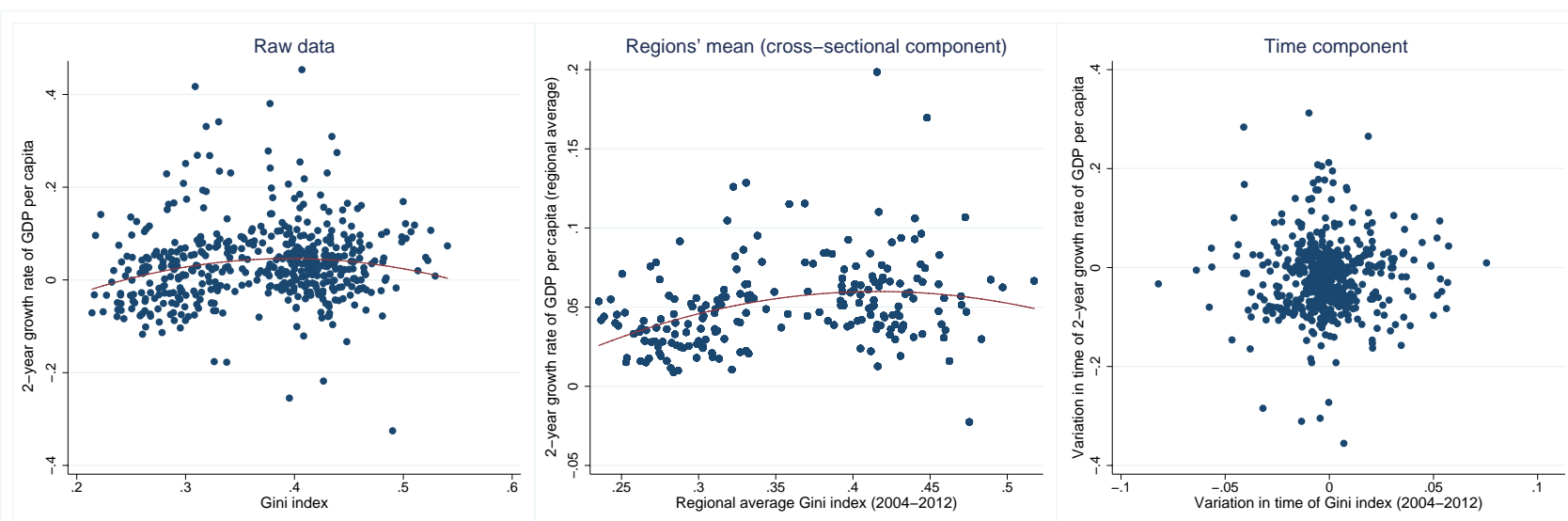

Source: Authors' elaboration based on national household income surveys, various years.

The raw correlation between economic growth and inequality is slightly positive (Table 4). This is more evident when the top decile ratio indicator is considered as a measure of inequality and it should be viewed together with recent findings which show that the increase of inequality during the crisis was mainly characterised by increasing wage differentials, with increases in the richest $10 \%$ earners over the poorest 10\% earners ratio (Cingano, 2014). However, the sign of the correlations changed when controlling for regions and time-fixed effects (Table 4). A closer look at the data shows that, in OECD regions, the relationship between inequality and growth seems to have changed in the periods before and after the economic crisis (Figure 4). In addition, strong macro-regional patterns emerge. By considering European and North American regions separately, it emerges more clearly that after the crisis more unequal regions grew relatively slower.

Table 4. Correlation coefficients between GDP and GDP per capita growth and inequality

\begin{tabular}{|c|c|c|c|c|c|c|}
\hline & Gini Index & p80-20 & p50-10 & p90-50 & pov60 & pov40 \\
\hline & \multicolumn{6}{|c|}{ Raw data } \\
\hline \multirow{3}{*}{$\begin{array}{l}\text { GDP growth } \\
\text { GDP per capita } \\
\text { growth }\end{array}$} & 0.117 & 0.101 & 0.052 & 0.143 & 0.061 & 0.054 \\
\hline & 0.050 & 0.058 & 0.044 & 0.073 & 0.023 & 0.040 \\
\hline & \multicolumn{6}{|c|}{ Adjusted data } \\
\hline GDP growth & -0.011 & -0.026 & -0.091 & -0.001 & -0.034 & -0.063 \\
\hline $\begin{array}{l}\text { GDP per capita } \\
\text { growth }\end{array}$ & 0.002 & -0.025 & -0.078 & 0.004 & -0.033 & -0.047 \\
\hline Observations & 597 & 588 & 587 & 588 & 597 & 597 \\
\hline
\end{tabular}


Figure 4. Income inequality and growth of GDP per capita: Pre- and post-crisis
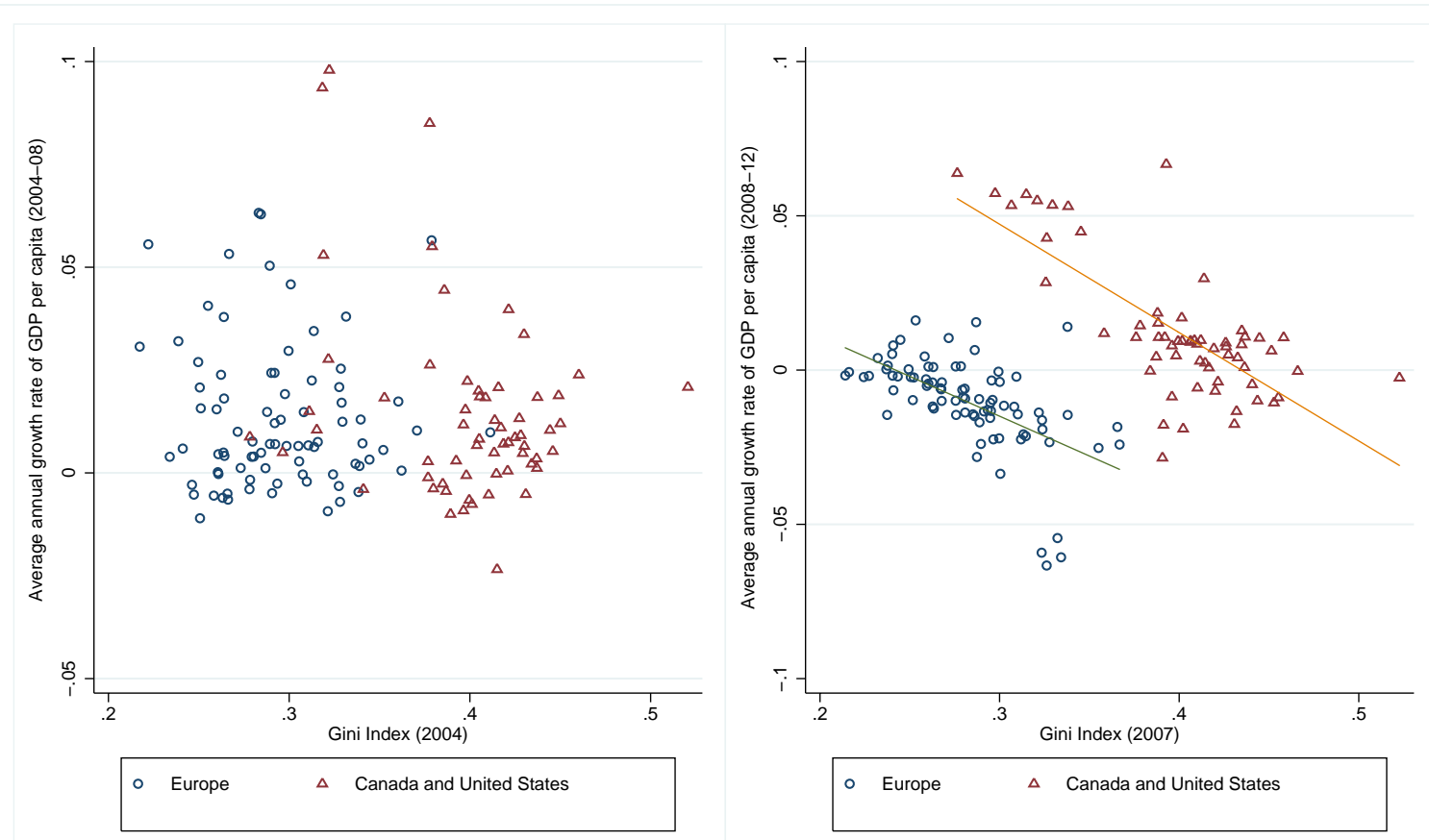

Source: Authors' elaboration based on national household income surveys and on the OECD Regional database.

\section{The role of urban concentration}

Urbanisation and income inequality can be interpreted as the concentration of human and physical capital in the process of development (Castells-Quintana and Royuela, 2014). By determining the allocation of resources across space and individuals, the interaction between urbanisation and inequality is therefore expected to have implications in terms of economic growth. The first step to enlightening this issue is to assess the levels of inequality in regions by distinguishing the type and size of urban settlements. Urban population was identified using the OECD functional urban areas (FUAs), which allows urban population within regions to be identified according to a consistent economic definition of city. Detailed explanations of this method are provided by OECD (2012). The idea is that FUAs are defined by first looking at high-density places (urban cores) through a $1 \mathrm{~km}^{2}$ global population grid and then by adding to the cores the surrounding territories that are connected to them through commuting flows. The use of a consistent definition of city across countries, based on functional criteria, is a relevant contribution of this study since it helps assess the extent of urban concentration within a region without relying on countries' existing administrative definitions of cities, which can be very different across countries and introduce biases in the analysis.

By matching regional (TL2) and urban (FUAs) boundaries it is possible to compute the share of urban population in each region by size of cities. In this respect, regions were classified in three groups: 88 regions where the largest urbanisation share is observed in smaller cities (less than 500,000 inhabitants), 63 in medium-sized cities (between 500,000 and 1.5 million inhabitants) and 53 in large cities (more than 1.5 million inhabitants). On the whole, inequalities are smaller the lower the size of cities, though a large heterogeneity emerges (Figure 5). More specifically, inequalities are, on average, higher in regions where the largest proportion of people lives in cities with more than 1.5 million inhabitants. This general evidence is robust to the use of several indicators of inequality, as reported in Table 5. Differences are particularly strong for poverty rates and for the bottom decile ratio (p50-10). 
Figure 5. Income inequality by urban size, OECD regions (2004-2012)

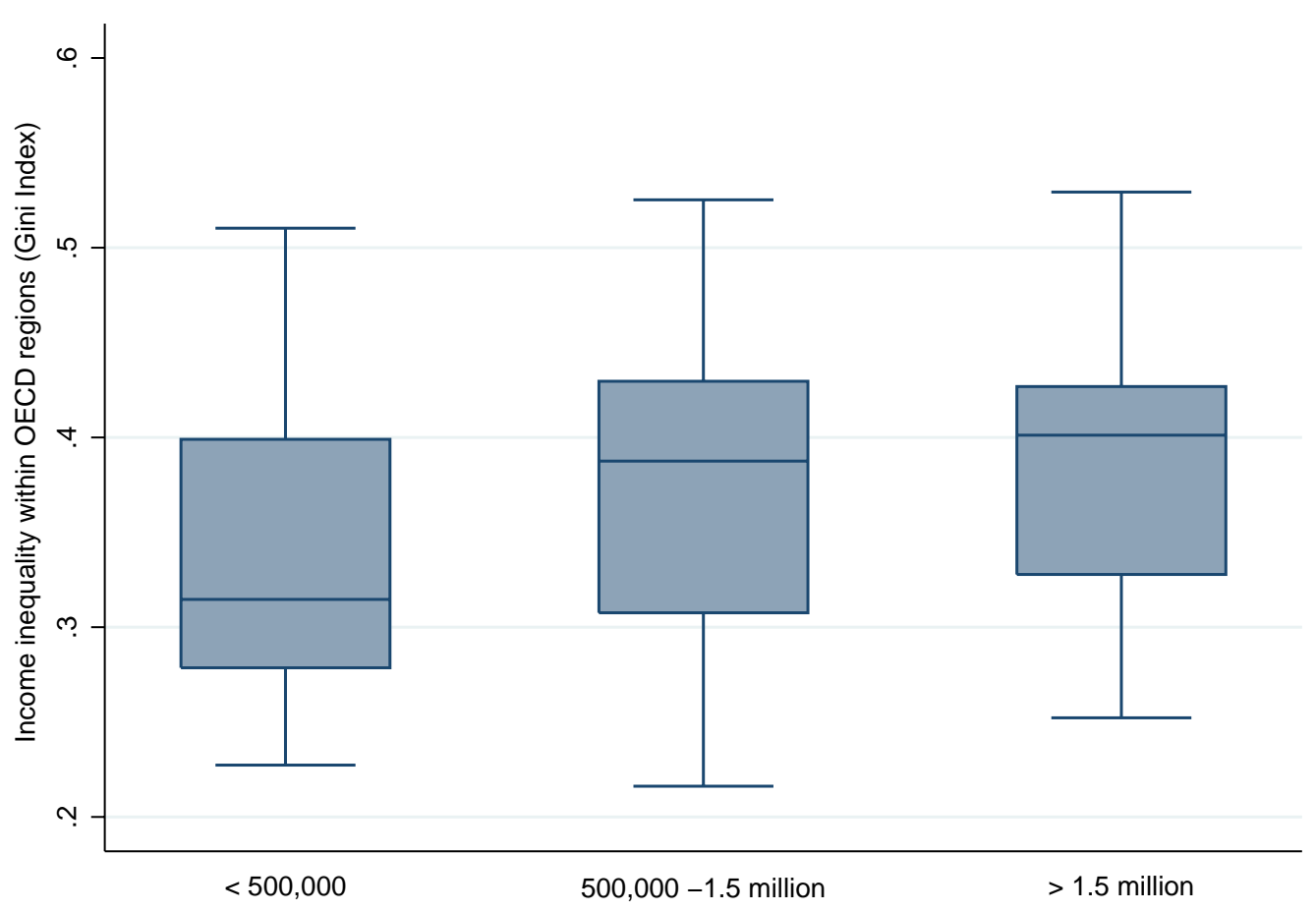

Table 5. Correlation between inequality and urbanisation rates

\begin{tabular}{|c|c|c|c|c|c|c|c|}
\hline & $\begin{array}{c}\text { Gini } \\
\text { Index }\end{array}$ & p80-20 & p90-10 & p90-50 & p50-10 & pov40 & pov60 \\
\hline Share of people living in FUAs of small size $(<500,000)$ & -0.163 & -0.160 & -0.155 & -0.123 & -0.127 & -0.132 & -0.135 \\
\hline $\begin{array}{l}\text { Share of people living in FUAs of medium size }(500,000- \\
1.5 \text { million }\end{array}$ & 0.086 & 0.033 & 30 & 0.012 & .098 & 0.013 & -0.001 \\
\hline Share of people living in FUAs of large size (>1.5 million) & 0.186 & 0.224 & 0.239 & 0.228 & 0.144 & 0.190 & 0.198 \\
\hline $\begin{array}{l}\text { Share of regional population living in FUAs (regardless of } \\
\text { size) }\end{array}$ & 0.168 & 0.169 & 0.191 & 0.166 & 0.161 & 0.132 & 0.126 \\
\hline
\end{tabular}

Several arguments can be put forward as a possible interpretation. First, more talented individuals tend to sort in large cities, where the returns to talent are higher and where there are more productive firms paying higher wages (Behrens et al., 2014). Second, agglomeration economies, reflected by urban size, can be source of additional wage premia, increasing in turn the level of inequalities. And finally, as proposed in the classic Harris and Todaro (1970) model, the expected income of a potential immigrant depends on the probability of finding a job, which is more likely to happen in expanding cities. Nevertheless, it can be the case that the inflow of workers in the urban sector exceeds urban labour demand, even when accompanied by growth of urban employment, which is the so-called Todaro paradox. This situation results in increasing unemployment in cities, which in turn increases inequality. This result, usually posed in rural-urban migration models, can also arise in situations where international migrants are directed to gateway cities, which are usually the larger ones (Royuela, forthcoming). As stressed recently in Lee et al. (2014), employment growth is more effective in reducing poverty and inequality than output growth. Overall, 
inequalities are becoming more important within cities and metropolitan areas than between regions (Weeks et al., 2006). Table 6 shows how regions with larger cities grew more than regions with smaller cities.

Table 6. Inequality and economic growth measures by urban size, OECD regions (2004-2012)

\begin{tabular}{|c|c|c|c|c|c|c|}
\hline & \multicolumn{6}{|c|}{$\begin{array}{c}\text { Cities 500,000-1.5 } \\
\text { million }\end{array}$} \\
\hline & Mean & Std. dev & Mean & Std. dev & Mean & Std. dev \\
\hline Gini Index & 0.338 & 0.073 & 0.368 & 0.073 & 0.384 & 0.062 \\
\hline p80-20 & 2.803 & 0.692 & 3.070 & 0.729 & 3.347 & 0.864 \\
\hline p90-10 & 5.150 & 1.974 & 5.907 & 2.123 & 6.819 & 2.805 \\
\hline p50-10 & 2.346 & 0.598 & 2.496 & 0.614 & 2.838 & 0.795 \\
\hline p90-50 & 2.148 & 0.440 & 2.321 & 0.456 & 2.346 & 0.395 \\
\hline pov60 & $19.39 \%$ & $5.55 \%$ & $21.01 \%$ & $5.56 \%$ & $23.18 \%$ & $5.34 \%$ \\
\hline pov40 & $7.90 \%$ & $4.57 \%$ & $9.07 \%$ & $4.73 \%$ & $11.36 \%$ & $5.15 \%$ \\
\hline $\begin{array}{l}\text { GDP growth } \\
\text { GDP per capita }\end{array}$ & $1.81 \%$ & $3.79 \%$ & $2.22 \%$ & $3.45 \%$ & $2.22 \%$ & $2.98 \%$ \\
\hline growth & $1.11 \%$ & $3.73 \%$ & $1.18 \%$ & $3.35 \%$ & $1.21 \%$ & $2.90 \%$ \\
\hline
\end{tabular}

\section{Empirical analysis}

\section{Model specification}

The standard procedure for estimating the impact of inequality on growth is to assume a simple linear relationship, where the growth rate of GDP per capita is regressed on a number of explanatory variables potentially explaining differences in such growth rates, including a measure of income inequality. Specifically,

$$
\ln y_{i t}-\ln y_{i t-\tau}=\alpha+\beta \ln y_{i t-\tau}+\gamma x_{i t-\tau}+\theta Z_{i t-\tau}+\varepsilon_{i t} \quad \text { [1] }
$$

where $\ln y_{i t}$ is the logarithm of GDP per capita in region $i$ at time $t ; x_{i t-\tau}$ represents an income inequality measure (e.g. the Gini Index), $Z_{i t-\tau}$ is a set of factors that explains economic growth and that is used as controls, and $\varepsilon_{i t}$ a random error term that varies across regions and periods. In this model, the coefficient $\beta$ will be related to the convergence rate across economies, while the coefficient $\gamma$ will allow the impact of income inequality within regions on growth to be assessed. As previously mentioned, studies based on cross-sectional regressions typically report a negative and significant relationship between initial income inequality and growth. The negative coefficient holds for different measures of inequality, samples of countries and time periods.

One of the main critiques to this kind of regression is that cross-sectional estimates may be biased due to omitted variables. Factors such as technology, climate, institutions and any other country-specific variable may be important determinants of growth rates and may be correlated with the explanatory variables considered in the model. Although a list of control variables can be included into the model, many other factors are typically unobservable. By assuming those factors are constant over time and using longitudinal rather than cross-sectional data, the suggested specification results in a modified panel data version of the previous equation, where one can control for unobservable factors using a fixed or random effects model. In particular, the modified model will adopt the following form:

$$
\ln y_{i t}-\ln y_{i t-\tau}=\alpha+\beta \ln y_{i t-\tau}+\gamma X_{i t-\tau}+\theta Z_{i t-\tau}+\Xi+\eta_{t}+\varepsilon_{i t},
$$

where $\eta_{t}$ represents a time-specific effect and $\Xi$ is a vector of region effects. 
The empirical model to be estimated faces a list of econometric problems: reverse causality, unobserved time-invariant region-specific characteristics and the presence of initial income as a regressor. The option of estimating a dynamic panel model using the System GMM estimator (Blundell and Bond, 1998), as in Halter et al. (2014), was discarded due to the too-short time dimension of our data set. Using regional fixed effects (FE) the estimated coefficients only reflect the time variation within regions. This procedure is supposed to account for the omitted variable bias. Nevertheless, it has a list of disadvantages: it reduces the degrees of freedom, the measurement-error bias is aggravated, as the signal-to-noise ratio is further reduced by only using variation within region. When the phenomenon under analysis mostly varies cross-sectionally, the FE methods may produce inaccurate results (Partridge, 2005). In our sample, the overall standard deviation of the Gini Index is 0.073 , with the between standard deviation at 0.070 and the within standard deviation 0.018 . Consequently, the FE models would only be using a small fraction of the variation of inequality, and "the long-run cross-sectional effects would be subsumed into the fixed effects" (Fallah and Partridge, 2007: 381), in turn producing potentially misleading results (Barro, 2000). In addition, the short time intervals considered in this work and in other similar analysis (Rodríguez-Pose and Tselios, 2010) further question the use of FE to account for the omitted variables bias.

The reverse causality problem in the context of the inequality-growth relationship will depend on the correlation between the error term and the regressors, such as the lagged endogenous and also the measurement of inequality. The choice between various different techniques to estimate the panel data model is governed by assumptions on such a correlation. Fixed effects models are helpful to partially solve this correlation. However, this approach is not appropriate to analyse the effect of variables that are fairly constant over time, or that will affect growth only in the long run, which could be the case for at least some of the mechanisms through which inequality can affect growth.

As none of the alternatives is optimal, we estimated all of the models in a panel framework: pooled regression, fixed and random effects estimates and the between models. This way we could also consider the possibility of different speeds of alternative transmission channels of inequality, as proposed in Halter et al. (2014). Indeed, in a model where the explanatory variables affect the endogenous variable by means of a distributed lag structure, the panel between estimates would capture the long-run effect while the fixed effects specification would capture short-run effects. Finally, the OLS and random effects models would report estimates averaging the long- and short-run specifications (Baltagi and Griffin, 1984; Pirotte, 1999). The potential endogeneity of the lagged value of GDP per capita and inequality was dealt with through an instrumental variable approach.

We have instrumented both inequality and lagged GDP per capita by means of the following variables: the murder rate, the share people with no religious affiliation and the share of Christians (which would be proxies of institutions and social issues), total population, the elderly rate and the urbanisation disaggregated by city size (which capture demographic characteristics and the spatial distribution of population), the average unemployment rate for the three previous years (a variable linked to labour market institutions) and finally, the lagged value of the interaction between inequality and GDP per capita, an internal instrument which is not capable of identifying transmission channels but works as a statistically sound instrument.

In order to account for the omitted-variable bias without incurring in the above-mentioned problems, we included 'macro-regional' dummies, which control for the continent where the region is located. ${ }^{3}$ In addition, a set of control variables were chosen according to the related literature. These included the sectoral share of the economy (agriculture, industry and construction), the urbanisation rate, the education

\footnotetext{
${ }^{3}$ Another possible option is the inclusion of country fixed effects. Nevertheless, several countries have a limited number of regions (two of them, Estonia and Luxemburg, have only one region) which poses some doubts on this strategy.
} 
levels, the labour market participation rate and one variable related to religion at the country level, based on a Herfindahl Index of diversity in religion. We also include time-fixed effects.

\section{Econometric results}

Table 7 shows the estimates of the pooled OLS panel estimates for different inequality measures. ${ }^{4}$ All specifications show a negative and significant coefficient associated to inequality. GDP per capita convergence arises only in two models, while disaggregated urbanisation is not significantly associated with economic growth. The labour force participation rate is always significant, while low education levels report statistically significantly negative coefficients. The sectoral composition shows significant parameters which, interestingly, are significantly positive for regions with high shares in construction. Finally, the variables related to religion report insignificant results.

The random effects and fixed effects specifications reported in Table 8 show that the long-run impact of inequality on economic growth in the analysed regions is clearly negative. On the contrary, the short-run fixed effects estimations report non-significant parameters. Finally, the specifications controlling for potential endogeneity of inequality and lagged level of GDP per capita report similar results: a nonsignificant impact of the evolution of inequality on GDP per capita growth rates and a negative impact of inequality levels on subsequent economic growth. This result reinforces the negative impact of inequality on economic growth, as far as the difference between the OLS and the instrumental variables (IV) estimates, which captures the size of endogeneity, implies a positive result, and consequently any endogeneity biases of OLS estimates tend to reduce the magnitude of the parameter of inequality.

It has to be acknowledged that the results emerging from the analysis carried out in the short timehorizon considered here are hardly comparable with works such as Partridge (2005) which covers a period of 40 years. In this latter work, a positive link between inequality and long-run economic growth was found for US states, while the FE results were much more ambiguous. Rodríguez-Pose and Tselios (2010) also found a positive link in OLS estimates and non-significant results for the FE results. Another important difference between their results and the ones shown here is that the years between 2004 and 2012 embed the deepest part of the economic crisis which began in 2008. Our results show that during the crisis inequality and economic growth were negatively associated. This confirms the intuitive correlations plotted in Figure 4 and suggests that more inclusive societies might represent an element of regional resilience. In terms of the channels that might underlie these results, it is possible that credit constraints and market size effects have been particularly important, which is a hypothesis that could be explored in further research.

The first stage of the instrumental variables analysis (not reported here, but available from the authors on request) allows the factors affecting inequality to be inspected: education, sectoral composition (with a strong influence of the construction sector) and labour market characteristics. These aspects also matter for economic growth. For example, persistent levels of unemployment combined with increasing inequality were found to harm economic growth (Castells-Quintana and Royuela (2012). A final factor that matters for inequality is the urban structure of the regions, an aspect that is further analysed in the remainder of this section.

\section{Accounting for urban size}

Table 9 reports the estimation of the previous model, incorporating inequality (Gini Index) multiplied by the three dummies for every type of region, plus the urban population shares in every type of city as

\footnotetext{
${ }^{4}$ We assume that the estimation of the top decile income in small samples, such as the ones considered at the analysed regions, can be problematic. Consequently, such results must be interpreted with caution.
} 
control variables. The results are presented for a set of alternative techniques. Two types of results deserve particular attention, on urbanisation and on inequality. First, the share of people living in larger cities displays a significant and positive result. This suggests that agglomeration economies allow regions to enjoy higher growth rates over the analysed period. Interestingly, the fixed effects model reports significant results for all urbanisation rates. This is in line with Barca et al. (2012), who report that economic growth does not need to depend on increasing urban concentration and, consequently, all types of growth processes are possible, not only the ones associated with regions with larger agglomerations.

Second, regions with higher levels of inequality are associated with lower economic growth, in line with previous results shown in Tables 7 and 8 . What is new in Table 9 is that the magnitude of the negative association between inequality and economic growth increases with city size. Thus, in regions mainly characterised by small cities or rural areas, the relationship between inequality and growth was weaker than in the rest of the regions.

These results are robust to various cross-sectional specifications (pooled OLS, between, random effects and instrumental variables). In summary, not only are inequalities are becoming more important within large cities and metropolitan areas, but in such regions the negative association between inequality and economic growth have been higher than in other regions. Again, the channels associated with such effects may be linked with credit market imperfections and to market size effects. One possible explanation might be related to stronger social ties in small cities and rural areas, which could limit the consequence of the imperfections in the credit markets. As for the market size effect, this might be linked to the high costs people face for living in cities (Combes et al., 2012), which are likely to depress particularly fixed salaries and government transfers and social benefits, usually established nationally rather than adjusted to local prices. Too high inequality might result in a weaker middle class, which can in turn harm economic growth (Partridge, 2005). 
Table 7. Pooled OLS estimates

\begin{tabular}{|c|c|c|c|c|c|c|c|}
\hline VARIABLES & $\begin{array}{l}(1) \\
\text { Gini }\end{array}$ & $\begin{array}{c}(2) \\
p 80-20\end{array}$ & $\begin{array}{c}(3) \\
\text { p90-10 }\end{array}$ & $\begin{array}{c}(4) \\
\text { p90-50 }\end{array}$ & $\begin{array}{c}(5) \\
p 50-10\end{array}$ & $\begin{array}{c}(6) \\
\text { pov40 }\end{array}$ & $\begin{array}{c}(7) \\
\text { pov60 }\end{array}$ \\
\hline In GDP per capita & $\begin{array}{l}-0.0110^{*} \\
(0.0061)\end{array}$ & $\begin{array}{c}-0.0072 \\
(0.0065)\end{array}$ & $\begin{array}{l}-0.0072 \\
(0.0065)\end{array}$ & $\begin{array}{l}-0.0100^{*} \\
(0.0060)\end{array}$ & $\begin{array}{l}-0.0073 \\
(0.0067)\end{array}$ & $\begin{array}{l}-0.0094 \\
(0.0065)\end{array}$ & $\begin{array}{l}-0.0093 \\
(0.0067)\end{array}$ \\
\hline Inequality & $\begin{array}{c}-0.1178^{* *} \\
(0.0472)\end{array}$ & $\begin{array}{c}-0.0084^{* *} \\
(0.0037)\end{array}$ & $\begin{array}{c}-0.0031^{\star *} \\
(0.0012)\end{array}$ & $\begin{array}{c}-0.0153^{* *} \\
(0.0076)\end{array}$ & $\begin{array}{c}-0.0076^{\star *} \\
(0.0033)\end{array}$ & $\begin{array}{c}-0.1039^{* *} \\
(0.0474)\end{array}$ & $\begin{array}{c}-0.0800^{* *} \\
(0.0398)\end{array}$ \\
\hline Urbanisation $<500,000$ & $\begin{array}{c}0.0031 \\
(0.0109)\end{array}$ & $\begin{array}{c}0.0016 \\
(0.0115)\end{array}$ & $\begin{array}{c}0.0036 \\
(0.0115)\end{array}$ & $\begin{array}{l}-0.0002 \\
(0.0111)\end{array}$ & $\begin{array}{c}0.0048 \\
(0.0114)\end{array}$ & $\begin{array}{c}0.0046 \\
(0.0111)\end{array}$ & $\begin{array}{c}0.0037 \\
(0.0111)\end{array}$ \\
\hline Urbanisation $500,000-1.5$ million & $\begin{array}{c}0.0034 \\
(0.0084)\end{array}$ & $\begin{array}{l}-0.0005 \\
(0.0087)\end{array}$ & $\begin{array}{c}0.0008 \\
(0.0086)\end{array}$ & $\begin{array}{c}0.0012 \\
(0.0085)\end{array}$ & $\begin{array}{c}0.0004 \\
(0.0086)\end{array}$ & $\begin{array}{c}0.0015 \\
(0.0086)\end{array}$ & $\begin{array}{c}0.0012 \\
(0.0087)\end{array}$ \\
\hline Urbanisation > 1.5 million & $\begin{array}{c}0.0101 \\
(0.0073)\end{array}$ & $\begin{array}{c}0.0030 \\
(0.0072)\end{array}$ & $\begin{array}{c}0.0038 \\
(0.0072)\end{array}$ & $\begin{array}{c}0.0050 \\
(0.0074)\end{array}$ & $\begin{array}{c}0.0032 \\
(0.0072)\end{array}$ & $\begin{array}{c}0.0067 \\
(0.0072)\end{array}$ & $\begin{array}{c}0.0068 \\
(0.0073)\end{array}$ \\
\hline Labour force participation rate & $\begin{array}{c}-0.0006^{* *} \\
(0.0003)\end{array}$ & $\begin{array}{c}-0.0007^{* *} \\
(0.0003)\end{array}$ & $\begin{array}{c}-0.0007^{* *} \\
(0.0003)\end{array}$ & $\begin{array}{c}-0.0006^{* *} \\
(0.0003)\end{array}$ & $\begin{array}{c}-0.0006^{* *} \\
(0.0003)\end{array}$ & $\begin{array}{c}-0.0006^{* *} \\
(0.0003)\end{array}$ & $\begin{array}{c}-0.0005^{* *} \\
(0.0003)\end{array}$ \\
\hline Education share in low levels (0-2 ISCED) & $\begin{array}{c}-0.0005^{* * *} \\
(0.0002)\end{array}$ & $\begin{array}{c}-0.0005^{* *} \\
(0.0002)\end{array}$ & $\begin{array}{c}-0.0005^{* * *} \\
(0.0002)\end{array}$ & $\begin{array}{c}-0.0004^{* *} \\
(0.0002)\end{array}$ & $\begin{array}{c}-0.0005^{* * *} \\
(0.0002)\end{array}$ & $\begin{array}{c}-0.0006^{* * *} \\
(0.0002)\end{array}$ & $\begin{array}{c}-0.0006^{* * *} \\
(0.0002)\end{array}$ \\
\hline Education share in high levels (5-6 ISCED) & $\begin{array}{c}0.0001 \\
(0.0002)\end{array}$ & $\begin{array}{c}0.0002 \\
(0.0002)\end{array}$ & $\begin{array}{c}0.0002 \\
(0.0002)\end{array}$ & $\begin{array}{c}0.0002 \\
(0.0002)\end{array}$ & $\begin{array}{c}0.0001 \\
(0.0002)\end{array}$ & $\begin{array}{c}0.0000 \\
(0.0002)\end{array}$ & $\begin{array}{c}0.0000 \\
(0.0002)\end{array}$ \\
\hline Industry share & $\begin{array}{l}0.0410^{*} \\
(0.0211)\end{array}$ & $\begin{array}{c}0.0322 \\
(0.0210)\end{array}$ & $\begin{array}{c}0.0310 \\
(0.0211)\end{array}$ & $\begin{array}{l}0.0421^{*} \\
(0.0215)\end{array}$ & $\begin{array}{c}0.0303 \\
(0.0210)\end{array}$ & $\begin{array}{l}0.0373^{*} \\
(0.0207)\end{array}$ & $\begin{array}{l}0.0399^{*} \\
(0.0210)\end{array}$ \\
\hline Agriculture share & $\begin{array}{c}0.1196 \\
(0.0751)\end{array}$ & $\begin{array}{c}0.1039 \\
(0.0730)\end{array}$ & $\begin{array}{c}0.1010 \\
(0.0729)\end{array}$ & $\begin{array}{c}0.1143 \\
(0.0737)\end{array}$ & $\begin{array}{c}0.0973 \\
(0.0733)\end{array}$ & $\begin{array}{c}0.1050 \\
(0.0736)\end{array}$ & $\begin{array}{c}0.1104 \\
(0.0740)\end{array}$ \\
\hline Construction share & $\begin{array}{c}0.2523^{* * *} \\
(0.0701)\end{array}$ & $\begin{array}{c}0.2471^{* * *} \\
(0.0741)\end{array}$ & $\begin{array}{c}0.2409^{* * *} \\
(0.0731)\end{array}$ & $\begin{array}{c}0.2332^{* * *} \\
(0.0719)\end{array}$ & $\begin{array}{c}0.2468^{* * *} \\
(0.0747)\end{array}$ & $\begin{array}{c}0.2762^{* * *} \\
(0.0762)\end{array}$ & $\begin{array}{c}0.2677^{\star \star \star} \\
(0.0736)\end{array}$ \\
\hline Religion diversity & $\begin{array}{c}0.0086 \\
(0.0086)\end{array}$ & $\begin{array}{c}0.0072 \\
(0.0089)\end{array}$ & $\begin{array}{c}0.0072 \\
(0.0088)\end{array}$ & $\begin{array}{c}0.0079 \\
(0.0089)\end{array}$ & $\begin{array}{c}0.0055 \\
(0.0088)\end{array}$ & $\begin{array}{c}0.0061 \\
(0.0086)\end{array}$ & $\begin{array}{c}0.0064 \\
(0.0087)\end{array}$ \\
\hline Constant & $\begin{array}{l}0.1700^{* *} \\
(0.0691)\end{array}$ & $\begin{array}{l}0.1200^{*} \\
(0.0717)\end{array}$ & $\begin{array}{c}0.1134 \\
(0.0729)\end{array}$ & $\begin{array}{l}0.1516^{* *} \\
(0.0716)\end{array}$ & $\begin{array}{c}0.1164 \\
(0.0737)\end{array}$ & $\begin{array}{l}0.1318^{*} \\
(0.0729)\end{array}$ & $\begin{array}{l}0.1323^{*} \\
(0.0742)\end{array}$ \\
\hline Continent fixed effects & Yes & Yes & Yes & Yes & Yes & Yes & Yes \\
\hline Time fixed effects & Yes & Yes & Yes & Yes & Yes & Yes & Yes \\
\hline Observations & 537 & 528 & 527 & 528 & 527 & 537 & 537 \\
\hline $\mathrm{R}^{2}$ & 0.493 & 0.482 & 0.482 & 0.480 & 0.478 & 0.488 & 0.487 \\
\hline
\end{tabular}


Table 8. Between, random, fixed effects and instrumental variables estimations of models for the Gini Index

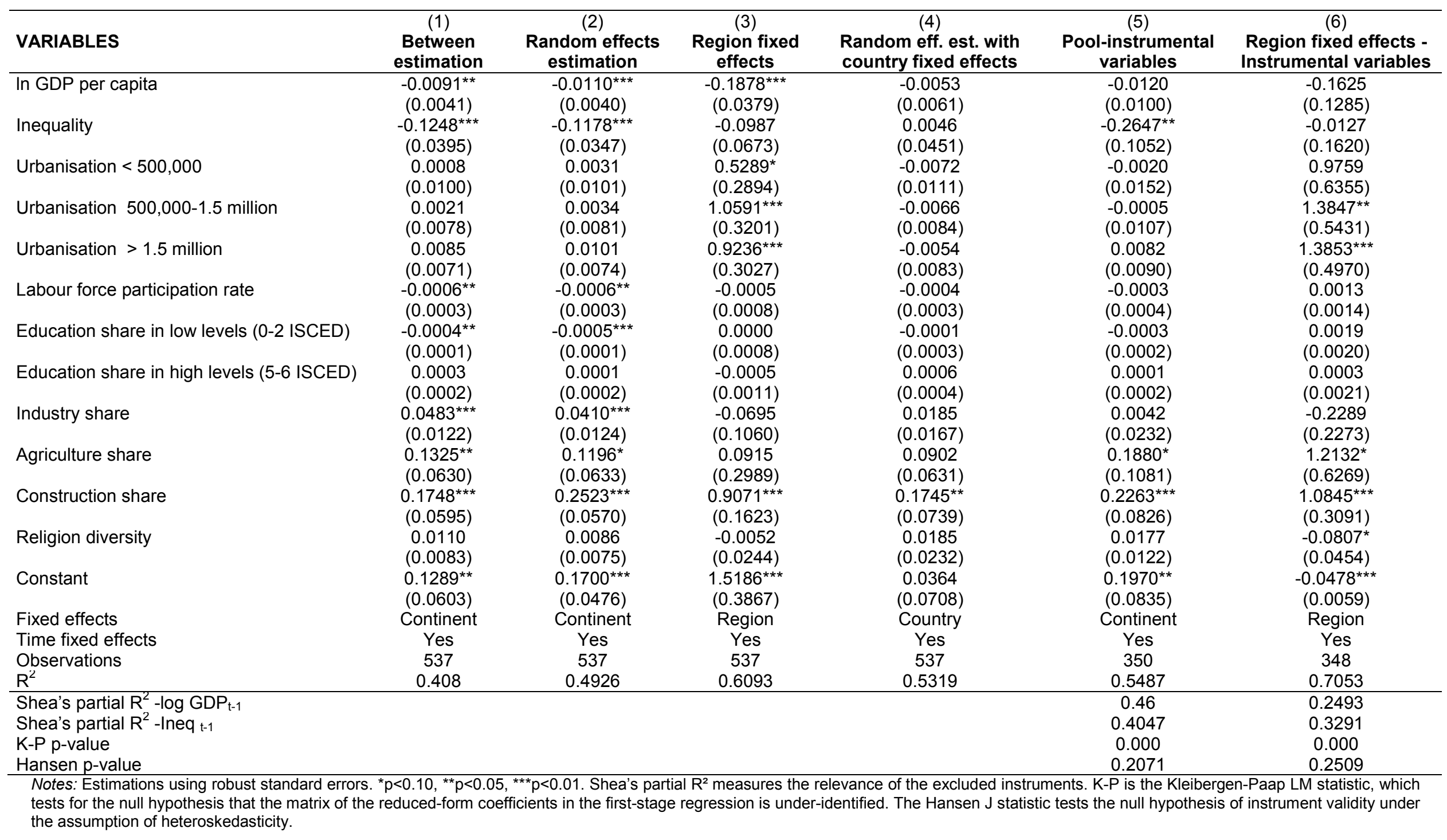


Table 9. Estimations of models for the Gini Index interacted with urban size

\begin{tabular}{|c|c|c|c|c|c|c|c|}
\hline VARIABLES & $\begin{array}{c}\text { (1) } \\
\text { Pooled OLS }\end{array}$ & $\begin{array}{c}(2) \\
\text { Between estimation }\end{array}$ & $\begin{array}{l}\text { (3) } \\
\text { RE }\end{array}$ & $\begin{array}{c}(4) \\
\text { Region FE }\end{array}$ & $\begin{array}{c}(5) \\
\text { RE country FE }\end{array}$ & $\begin{array}{c}(6) \\
\text { Pooled-IV }\end{array}$ & $\begin{array}{c}(7) \\
\text { Region FE-IV }\end{array}$ \\
\hline In GDP per capita & $\begin{array}{c}-0.0117^{\star \star \star} \\
(0.0041)\end{array}$ & $\begin{array}{l}-0.0101^{* *} \\
(0.0041)\end{array}$ & $\begin{array}{c}-0.0117^{\star * *} \\
(0.0041)\end{array}$ & $\begin{array}{c}-0.1852^{\star \star \star *} \\
(0.0379)\end{array}$ & $\begin{array}{l}-0.0091 \\
(0.0063)\end{array}$ & $\begin{array}{l}-0.0122 \\
(0.0079)\end{array}$ & $\begin{array}{l}-0.0942 \\
(0.1472)\end{array}$ \\
\hline Ineq * Urb $<500,000$ & $\begin{array}{c}-0.0912^{* *} \\
(0.0366)\end{array}$ & $\begin{array}{c}-0.0974^{* *} \\
(0.0413)\end{array}$ & $\begin{array}{c}-0.0912^{\star *} \\
(0.0366)\end{array}$ & $\begin{array}{c}0.0069 \\
(0.0943)\end{array}$ & $\begin{array}{c}0.0175 \\
(0.0462)\end{array}$ & $\begin{array}{c}-0.2207^{\star * *} \\
(0.0752)\end{array}$ & $\begin{array}{c}0.0544 \\
(0.2464)\end{array}$ \\
\hline Ineq * Urb 500,000-1.5 million & $\begin{array}{c}-0.1153^{* * *} \\
(0.0345)\end{array}$ & $\begin{array}{c}-0.1166^{\star * *} \\
(0.0388)\end{array}$ & $\begin{array}{c}-0.1153^{* * *} \\
(0.0345)\end{array}$ & $\begin{array}{c}-0.2354^{* *} \\
(0.1106)\end{array}$ & $\begin{array}{l}-0.0044 \\
(0.0452)\end{array}$ & $\begin{array}{c}-0.2486^{* * *} \\
(0.0706)\end{array}$ & $\begin{array}{c}0.0121 \\
(0.2400)\end{array}$ \\
\hline Ineq * Urb > 1.5 million & $\begin{array}{c}-0.1434^{* * *} \\
(0.0374)\end{array}$ & $\begin{array}{c}-0.1449^{\star \star \star *} \\
(0.0414)\end{array}$ & $\begin{array}{c}-0.1434^{* * *} \\
(0.0374)\end{array}$ & $\begin{array}{l}-0.1263 \\
(0.1888)\end{array}$ & $\begin{array}{l}-0.0190 \\
(0.0490)\end{array}$ & $\begin{array}{c}-0.2747^{* * *} \\
(0.0734)\end{array}$ & $\begin{array}{c}0.0698 \\
(0.6120)\end{array}$ \\
\hline Urbanisation $<500,000$ & $\begin{array}{c}0.0018 \\
(0.0101)\end{array}$ & $\begin{array}{c}0.0004 \\
(0.0099)\end{array}$ & $\begin{array}{c}0.0018 \\
(0.0101)\end{array}$ & $\begin{array}{l}0.5723^{\star *} \\
(0.2904)\end{array}$ & $\begin{array}{l}-0.0066 \\
(0.0112)\end{array}$ & $\begin{array}{c}-0.0039 \\
(0.0131)\end{array}$ & $\begin{array}{c}0.8294 \\
(0.6536)\end{array}$ \\
\hline Urbanisation $500,000-1.5$ million & $\begin{array}{c}0.0160 \\
(0.0111)\end{array}$ & $\begin{array}{c}0.0123 \\
(0.0106)\end{array}$ & $\begin{array}{c}0.0160 \\
(0.0111)\end{array}$ & $\begin{array}{c}1.0476^{* * *} \\
(0.3202)\end{array}$ & $\begin{array}{c}0.0070 \\
(0.0116)\end{array}$ & $\begin{array}{c}0.0142 \\
(0.0140)\end{array}$ & $\begin{array}{l}1.4570^{* * *} \\
(0.5655)\end{array}$ \\
\hline Urbanisation $>1.5$ million & $\begin{array}{c}0.0346^{* * *} \\
(0.0114)\end{array}$ & $\begin{array}{c}0.0313^{\star * *} \\
(0.0107)\end{array}$ & $\begin{array}{c}0.0346^{* * \star} \\
(0.0114)\end{array}$ & $\begin{array}{c}0.9230^{\star \star *} \\
(0.3024)\end{array}$ & $\begin{array}{c}0.0139 \\
(0.0138)\end{array}$ & $\begin{array}{l}0.0329^{\star \star} \\
(0.0145)\end{array}$ & $\begin{array}{l}1.3874^{* \star *} \\
(0.5237)\end{array}$ \\
\hline Labour force participation rate & $\begin{array}{l}-0.0005^{*} \\
(0.0003)\end{array}$ & $\begin{array}{l}-0.0005 \\
(0.0003)\end{array}$ & $\begin{array}{l}-0.0005^{\star} \\
(0.0003)\end{array}$ & $\begin{array}{l}-0.0005 \\
(0.0008)\end{array}$ & $\begin{array}{l}-0.0003 \\
(0.0003)\end{array}$ & $\begin{array}{l}-0.0002 \\
(0.0004)\end{array}$ & $\begin{array}{c}0.0015 \\
(0.0014)\end{array}$ \\
\hline Education share in low levels (0-2 ISCED) & $\begin{array}{c}-0.0005^{* * *} \\
(0.0001)\end{array}$ & $\begin{array}{c}-0.0004^{* *} \\
(0.0001)\end{array}$ & $\begin{array}{c}-0.0005^{* * *} \\
(0.0001)\end{array}$ & $\begin{array}{c}0.0001 \\
(0.0008)\end{array}$ & $\begin{array}{l}-0.0000 \\
(0.0003)\end{array}$ & $\begin{array}{l}-0.0003 \\
(0.0002)\end{array}$ & $\begin{array}{c}0.0018 \\
(0.0020)\end{array}$ \\
\hline Education share in high levels (5-6 ISCED) & $\begin{array}{l}-0.0000 \\
(0.0002)\end{array}$ & $\begin{array}{c}0.0002 \\
(0.0002)\end{array}$ & $\begin{array}{l}-0.0000 \\
(0.0002)\end{array}$ & $\begin{array}{l}-0.0005 \\
(0.0011)\end{array}$ & $\begin{array}{c}0.0006 \\
(0.0004)\end{array}$ & $\begin{array}{c}0.0000 \\
(0.0003)\end{array}$ & $\begin{array}{l}-0.0001 \\
(0.0023)\end{array}$ \\
\hline Industry share & $\begin{array}{c}0.0421^{\star * *} \\
(0.0123)\end{array}$ & $\begin{array}{c}0.0498^{* * *} \\
(0.0120)\end{array}$ & $\begin{array}{c}0.0421^{\star \star \star} \\
(0.0123)\end{array}$ & $\begin{array}{l}-0.0790 \\
(0.1060)\end{array}$ & $\begin{array}{l}0.0266 \\
(0.0172)\end{array}$ & $\begin{array}{c}0.0069 \\
(0.0160)\end{array}$ & $\begin{array}{l}-0.3185 \\
(0.2485)\end{array}$ \\
\hline Agriculture share & $\begin{array}{l}0.1139^{\star} \\
(0.0630)\end{array}$ & $\begin{array}{l}0.1230^{* *} \\
(0.0619)\end{array}$ & $\begin{array}{l}0.1139^{*} \\
(0.0630)\end{array}$ & $\begin{array}{c}0.0734 \\
(0.2991)\end{array}$ & $\begin{array}{c}0.0882 \\
(0.0631)\end{array}$ & $\begin{array}{l}0.1921^{* *} \\
(0.0865)\end{array}$ & $\begin{array}{l}1.1796^{*} \\
(0.6439)\end{array}$ \\
\hline Construction share & $\begin{array}{c}0.2445^{\star * *} \\
(0.0569)\end{array}$ & $\begin{array}{c}0.1677^{* * *} \\
(0.0589)\end{array}$ & $\begin{array}{c}0.2445^{* \star *} \\
(0.0569)\end{array}$ & $\begin{array}{c}0.9047^{* * *} \\
(0.1623)\end{array}$ & $\begin{array}{l}0.1721^{* *} \\
(0.0747)\end{array}$ & $\begin{array}{c}0.2184^{* * *} \\
(0.0705)\end{array}$ & $\begin{array}{c}0.9657^{* * *} \\
(0.3286)\end{array}$ \\
\hline Religion diversity & $\begin{array}{c}0.0110 \\
(0.0075)\end{array}$ & $\begin{array}{l}0.0144^{*} \\
(0.0082)\end{array}$ & $\begin{array}{c}0.0110 \\
(0.0075)\end{array}$ & $\begin{array}{c}0.0006 \\
(0.0246)\end{array}$ & $\begin{array}{c}0.0191 \\
(0.0231)\end{array}$ & $\begin{array}{l}0.0212^{\star *} \\
(0.0105)\end{array}$ & $\begin{array}{l}-0.0849^{\star} \\
(0.0478)\end{array}$ \\
\hline Constant & $\begin{array}{c}0.1624^{* * *} \\
(0.0474)\end{array}$ & $\begin{array}{l}0.1201^{* *} \\
(0.0593)\end{array}$ & $\begin{array}{c}0.1624^{* * *} \\
(0.0474)\end{array}$ & $\begin{array}{l}1.4776^{* * *} \\
(0.3871)\end{array}$ & $\begin{array}{c}0.0587 \\
(0.0714)\end{array}$ & $\begin{array}{l}0.1708^{* *} \\
(0.0770)\end{array}$ & $\begin{array}{c}-0.0492^{* * *} \\
(0.0064)\end{array}$ \\
\hline Fixed effects & Continent & Continent & Continent & Region & Country & Continent & Region \\
\hline Time fixed effects & Yes & Yes & Yes & Yes & Yes & Yes & Yes \\
\hline Observations & 537 & 537 & 537 & 537 & 537 & 350 & 348 \\
\hline$R^{2}$ & 0.501 & 0.405 & 0.524 & 0.613 & 0.518 & 0.558 & 0.696 \\
\hline $\begin{array}{l}\text { Shea's partial } R^{2} \text { - log GDPt-1 } \\
\left.\text { Shea's partial } R^{2} \text { - Ineq } t-1 \text { (URB }<500,000\right) \\
\text { Shea's partial } R^{2} \text { - Ineq } t-1 \text { (URB 500,000-1.5 million) } \\
\text { Shea's partial } R^{2} \text { - Ineq t-1 (URB > 1.5 million) } \\
\text { Under identification test - Anderson canon. corr. LM statistic ( } P \text { value) } \\
\text { Hansen p-value }\end{array}$ & & & & & & $\begin{array}{l}0.439 \\
0.385 \\
0.399 \\
0.420 \\
0.000 \\
0.269\end{array}$ & $\begin{array}{l}0.201 \\
0.270 \\
0.396 \\
0.209 \\
0.000 \\
0.340\end{array}$ \\
\hline
\end{tabular}
tests for the null hypothesis that the matrix of the reduced-form coefficients in the first-stage regression is under-identified. The Hansen $J$ statistic tests the null hypothesis of instrument validity under the assumption of heteroskedasticity. 


\section{Sensitivity analysis: Time of inequality}

The variability in the results of the impact of inequality on economic growth has been a constant in the applied literature. The changing sign of the inequality-growth relationship is linked to the transmission channel playing a major role, which is likely to change in different circumstances. Thus, positive and negative results have been found depending on the level of a country's development (Partridge, 1997; Barro, 2000), on the initial income distribution itself (Chen, 2003), on the profile of inequality (Voitchovsky, 2005) or on the process of urbanisation (Castells-Quintana and Royuela, 2014). Similarly, the time horizon perspective has been underlined as a variable showing different parameters for the inequality-growth relationships (Forbes, 2000; Halter et al., 2014).

The impact of inequality on economic growth in OECD regions has changed over time. The period of analysis of this research is clearly influenced by the Great Recession that started in 2007/08. The available sample includes information of inequality in four points of time: 2004, 2007, 2010 and 2012. As for GDP growth, the last available year is 2010. Consequently, we can only divide the sample into two sub-periods: 2004-2007 and 2007-2010.

The results, reported in Table 10, show a negative and significant inequality-growth relationship after 2007, while non-significant parameters were found for the previous period. This confirms the idea that inclusiveness might have been relevant as an element of regional resilience against the shock of the crisis. When we disaggregate the results by urban size, we find the same results as above, but again only in the second sub-period. Regions with smaller cities show a positive and significant impact of inequality. This result suggests, consistently with Castells-Quintana and Royuela (2014), that places with lower levels of inequality - as regions with relatively small cities - might have space for increasing inequality by increasing the spatial concentration of economic activity. As large cities have a relatively high inequality, regions characterised by small and medium-sized cities can still benefit from urban concentration, but at the cost of higher inequalities. This hypothesis might explain the positive coefficient encountered between inequality and growth for less urbanised regions. 
Table 10. Estimation of models by sub-periods

\begin{tabular}{|c|c|c|c|c|c|c|c|c|}
\hline VARIABLES & $\begin{array}{l}\text { Pooled } \\
\text { OLS }\end{array}$ & $\begin{array}{c}\text { Pooled } \\
\text { IV }\end{array}$ & $\begin{array}{l}\text { Pooled } \\
\text { OLS }\end{array}$ & $\begin{array}{c}\text { Pooled } \\
\text { IV }\end{array}$ & $\begin{array}{l}\text { Pooled } \\
\text { OLS }\end{array}$ & $\begin{array}{c}\text { Pooled } \\
\text { IV }\end{array}$ & $\begin{array}{c}\text { Pooled } \\
\text { OLS }\end{array}$ & $\begin{array}{c}\text { Pooled } \\
\text { IV }\end{array}$ \\
\hline Inequality & $\begin{array}{l}0.0615 \\
(0.047)\end{array}$ & $\begin{array}{r}-0.0873 \\
(0.081)\end{array}$ & $\begin{array}{c}-0.2485^{\star * *} \\
(0.057)\end{array}$ & $\begin{array}{c}-0.329^{\star \star *} \\
(0.089)\end{array}$ & & & & \\
\hline Ineq * Urb $<500,000$ & & & & & $\begin{array}{c}0.0885^{*} \\
(0.049)\end{array}$ & $\begin{array}{c}0.1499 * \\
(0.085)\end{array}$ & $\begin{array}{c}-0.2214^{* * *} \\
(0.058)\end{array}$ & $\begin{array}{c}-0.221^{* * *} \\
(0.075)\end{array}$ \\
\hline Ineq * Urb 500,000-1.5 million & & & & & $\begin{array}{l}0.0649 \\
(0.047)\end{array}$ & $\begin{array}{l}0.0494 \\
(0.065)\end{array}$ & $\begin{array}{c}-0.2493^{* * *} \\
(0.056)\end{array}$ & $\begin{array}{c}-0.249^{* * *} \\
(0.071)\end{array}$ \\
\hline Ineq * Urb > 1.5 million & & & & & $\begin{array}{l}0.0391 \\
(0.051)\end{array}$ & $\begin{array}{l}0.0484 \\
(0.084)\end{array}$ & $\begin{array}{c}-0.2755^{* * *} \\
(0.062)\end{array}$ & $\begin{array}{c}-0.275^{\star \star \star} \\
(0.074)\end{array}$ \\
\hline Observations & 351 & 338 & 362 & 537 & 351 & 318 & 362 & 350 \\
\hline $\mathrm{R}^{2}$ & 0.595 & 0.527 & 0.541 & 0.546 & 0.604 & 0.555 & 0.549 & 0.558 \\
\hline Shea's partial $R^{2}$ - log GDPt-1 & & 0.2732 & & 0.6104 & & 0.3454 & & 0.4281 \\
\hline Shea's partial $\mathrm{R}^{2}$ - Ineq t-1 (URB > 1.5 million) & & & & & & 0.2515 & & 0.4173 \\
\hline Under identification test ( $P$ value $)$ & & 0.000 & & 0.000 & & 0.0438 & & 0.0000 \\
\hline Hansen p-value & & 0.1408 & & 0.1044 & & 0.1576 & & 0.1867 \\
\hline
\end{tabular}

Note: All estimates include controls, continent-fixed effects and time-fixed effects. 


\section{Concluding remarks}

The first objective of this paper was to analyse the relationship between income inequality and economic growth in a panel of regions from 15 different OECD countries covering three continents over the period between 2004 and 2012. With this aim, we have computed indicators of inequality at regional level using micro-data from the household income surveys available in each country and have regressed the growth rate of GDP per capita on these indicators together with the usual controls in the literature. The obtained results, which have been subjected to several robustness checks, provide support of the negative correlation between inequality and economic growth, especially since the start of the economic crisis.

The second objective of this paper was to analyse how the relationship between inequality and growth changes with the degree and type of urban concentration. The considered regions were grouped into three classes: less than 500,000 inhabitants; between 500,000 and 1.5 million inhabitants; and more than 1.5 million inhabitants. A descriptive analysis showed that inequalities are lower the lower the size of the city. Econometric results have then shown that the association between inequality and economic growth is sensitive to the type of urban structure. Higher inequalities seem to be more detrimental in regions with medium-large cities, while small cities and rural areas with higher levels of inequalities grow faster. Credit market imperfections and market size effects could be part of the story behind the obtained results. If imperfections in the credit market are lower in less-populated areas due to less-asymmetric information flows and higher proximity and closer contacts, this could lead to lower inequality and, at the same time, to better incentives to wealth accumulation and higher economic growth. The market size channel could operate in the opposite direction: the higher costs of living in an urban area are not equally shared by its inhabitants, thus increasing within-regional inequalities and, at the same time, depressing economic growth due to the fact that fewer consumers can afford to buy more goods. A sensitivity analysis was developed in order to check for a changing relationship over time and over different groups of regions by level of inequality. The results stress the role of the Great Recession, which arises as the main driver for empowering the negative channels of inequality. From another perspective, this result suggests that having low inequality might improve regions' resilience to shocks, such as economic crises.

Future research could advance in two different, although related, directions: first, exploring the reasons underlying the increasing importance of inequality within cities and metropolitan areas than between regions is a relevant and scarcely analysed topic and, second, testing alternative theories on the mechanisms through which urban size can alter the relationship between inequality and economic growth. 


\section{REFERENCES}

Aghion, Philippe and Patrick Bolton. 1990. "Government Domestic Debt and the Risk of Default: A Political Economic Model of the Strategic Role of Debt," in Rudiger Dornbusch and Mario Draghi, eds., Public Debt Management: Theory and History. Cambridge: Cambridge University Press.

Aghion, Philippe, Eve Caroli and Cecilia García-Peñalosa. 1999a. "Inequality and Economic Growth: The Perspective of the New Growth Theories," Journal of Economic Literature, 37, 1615-1660.

Aghion, Philippe, Abhijit Banerjee and Thomas Piketty. 1999b. "Dualism and Macroeconomic Volatility," The Quarterly Journal of Economics, 114(4), 1359-1397.

Akerlof, George A. and Janet L. Yellen. 1990. "The Fair Wage-effort Hypothesis and Unemployment," The Quarterly Journal of Economics, 105(2), 255-283.

Alesina, Alberto and Roberto Perotti. 1996. "Income Distribution, Political Instability, and Investment," European Economic Review, 40, 1203-1228.

Alesina, Alberto and Dani Rodrik. 1994. "Distributive Politics and Economic Growth", The Quarterly Journal of Economics, 109, 465-490.

Baltagi, Badi H. and James M. Griffin. 1984. "Short and Long Run Effects in Pooled Models," International Economic Review, 25(3), 631-645.

Barca, Fabrizio, Philip McCann and Andrés Rodríguez-Pose. 2012. "The Case for Regional Development Intervention: Place-based Versus Place-neutral Approaches," Journal of Regional Science, 52(1), $134-152$.

Barro, Robert J. 2000. "Inequality and Growth in a Panel of Countries," Journal of Economic Growth, 5, 5-32.

Behrens, Kristian, Gilles Duranton and Frédéric Robert-Nicoud. 2014. "Productive Cities: Sorting, Selection and Agglomeration," Journal of Political Economy, 122(3), 507-553.

Bénabou, Roland. 2002. "Tax and Education Policy in a Heterogeneous-Agent Economy: What Levels of Redistribution Maximize Growth and Efficiency?," Econometrica, 70(2), 471-517.

Bertola, Giuseppe, Reto Foellmi and Josef Zweimüller. 2006. Income Distribution in Macroeconomic Models. Princeton: Princeton University Press.

Blundell, Richard and Stephen Bond. 1998. "Initial Conditions and Moment Restrictions in Dynamic Panel Data Models," Journal of Econometrics, 87, 115-143.

Brescia, Raymond H. 2010. "The Cost of Inequality: Social Distance, Predatory Conduct, and the Financial Crisis," NYU Annual Survey of American Law, 66.

Castells-Quintana, David and Vincente Royuela. 2012. "Unemployment and Long-run Economic Growth: The Role of Income Inequality and Urbanisation,” Investigaciones Regionales, 24, 153-173. 
Castells-Quintana, David and Vincente Royuela. 2014. "Agglomeration, Inequality and Economic Growth," Annals of Regional Science, 52, 343-366.

Causa, Orsetta and Åsa Johansson. 2009. "Intergenerational Social Mobility," OECD Economics Department Working Papers, 707. Paris: OECD Publishing.

Chen, Been-Lon. 2003. "An Inverted-U Relationship Between Inequality and Long-run Growth," Economics Letters, 78(2), 205-212.

Cingano, Federico (2014), "Trends in Income Inequality and its Impact on Economic Growth," OECD Social, Employment and Migration Working Papers, 163. Paris: OECD Publishing.

Combes, Pierre-Philippe, Gilles Duranton and Laurent Gobillon. 2012. "The Cost of Agglomeration: Land Prices in French Cities," CEPR Working Papers, 9240.

De Dominicis, Laura, Raymond J.G.M. Florax and Henri L.F. de Groot. 2008. "Meta-analysis of the Relationship Between Income Inequality and Economic Growth," Scottish Journal of Political Economy, 55(5), 654-682.

Dynan, Karen E., Jonathan Skinner and Stephen P. Zeldes. 2004. "Do the Rich Save More?," Journal of Political Economy, 112(2), 397-444.

Easterly, William. 2001. "The Middle Class Consensus and Economic Development," Journal of Economic Growth, 6, 317-335.

Easterly, William. 2007. "Inequality Does Cause Underdevelopment: Insights from a New Instrument," Journal of Development Economics, 84, 755-776.

Ehrhart, Christophe. 2009. "The Effects of Inequality on Growth: A Survey of the Theoretical and Empirical Literature,” ECINEQ Working Paper Series, 2009-107.

Ezcurra, Roberto. 2010. "Does Income Polarization Affect Economic Growth? The Case of the European Regions," Regional Studies, 43(2), 267-285.

Fallah, Belal N. and Mark Partridge. 2007. "The Elusive Inequality-Economic Growth Relationship: Are There Differences Between Cities and Countries," The Annals of Regional Science, 41(2), 375-400.

Forbes, Kristine J. (2000), "A Reassessement of the Relationship Between Inequality and Growth," American Economic Review, 90(4): 869-887.

Frank, Mark W. 2009. "Inequality and Growth in the United States: Evidence From a New State-level Panel of Income Inequality Measures," Economic Inquiry, 47(1), 55-68.

Galor, Oded. 2000. "Income Distribution and the Process of Development," European Economic Review, 44, 706-712.

Galor, Oded. 2009. Inequality and Economic Development: The Modern Perspective. Edward Elgar Pub. Ltd.

Galor, Oded and Omer Moav. 2004. "From Physical to Human Capital Accumulation: Inequality and the Process of Development," Review of Economic Studies, 71(4), 1001-1026. 
Galor, Oded and Joseph Zeira. 1993. "Income Distribution and Macroeconomics," The Review of Economic Studies, 60(1), 35-52.

Halter, Daniel, Manuel Oechslin and Joseph Zweimüller. 2014. "Inequality and Growth: The Neglected Time Dimension,” Journal of Economic Growth, 19, 81-104.

Harris, John R. and Michael P. Todaro. 1970. "Migration, Unemployment and Development: A Two-sector Analysis," American Economic Review, 60, 126-142.

Janikas, Mark V. and Sergio J. Rey. 2008. "On the Relationships Between Spatial Clustering, Inequality, and Economic Growth in the United States: 1960-2000," Region et Development, 27, 13-34.

Kaldor, Nicholas. 1957. “A Model of Economic Growth,” Economic Journal, 67, 591-624.

Krugman, Paul. 2008. The Return of Depression Economics and the Crisis of 2008. London: Penguin.

Lee, Neil, Paul Sissons, Ceri Hughes, Anne Green, Gaby Atfield, Duncan Adam and Andrés RodríguezPose. 2014. Cities, Growth and Poverty: Evidence Review. York: Joseph Rowntree Foundation.

Neves, Pedro Cunha and Sandra Tavares Silva. 2014. "Inequality and Growth: Uncovering the Main Conclusions from the Empirics," Journal of Development Studies, 50(1), 1-21.

OECD (2011), Divided We Stand: Why Inequality Keeps Rising, OECD Publishing, Paris, http://dx.doi.org/10.1787/9789264119536-en.

OECD (2012), Redefining "Urban": A New Way to Measure Metropolitan Areas, OECD Publishing, Paris http://dx.doi.org/10.1787/9789264174108-en.

OECD (2013), OECD Regions at a Glance 2013, OECD Publishing, Paris, http://dx.doi.org/10.1787/reg glance-2013-en.

OECD (2014a), "New Approaches to Economic Challenges (NAEC)", Synthesis report, presented at the Meeting of the OECD council at ministerial Level, Paris, 6-7 May, http://www.oecd.org/mcm/CMIN\%282014\%292-ENG.pdf.

OECD (2014b), How's Life in Your Region?: Measuring Regional and Local Well-being for Policy Making, OECD Publishing, Paris, http://dx.doi.org/10.1787/9789264217416-en.

OECD/The World Bank. 2012. Promoting Inclusive Growth. Challenges and Policy. Paris: OECD Publishing.

OECD/The World Bank (2012), Promoting Inclusive Growth: Challenges and Policies, OECD Publishing, Paris, http://dx.doi.org/10.1787/9789264168305-en.

Panizza, Ugo. 2002. "Income Inequality and Economic Growth: Evidence from American Data," Journal of Economic Growth, 7, 25-41.

Partridge, Mark D. 1997. "Is Inequality Harmful for Growth? Comment," American Economic Review, 87(5), 1019-1031.

Partridge, Mark D. 2005. "Does Income Distribution Affect US State Economic Growth?," Journal of Regional Science, 45, 363-394. 
Partridge, Mark D. 2006. "The Relationship Between Inequality and Labour Market Performance: Evidence from U.S. States," Journal of Labour Research, 27(1), 1-20.

Persson, Torsten and Guido Tabellini. 1994. "Is Inequality Harmful for Growth? Theory and Evidence," American Economic Review, 84, 600-621.

Perugini, Cristiano and Gaetano Martino. 2008. "Income Inequality Within European Regions: Determinants and Effects on Growth," Review of Income and Wealth, 54, 373-406.

Piacentini, Mario. 2014. "Measuring Income Inequality and Poverty at the Regional Level in OECD Countries," OECD Statistics Working Papers, 2014/03, Paris: OECD Publishing.

Pirotte, Alain. 1999. "Convergence of the Static Estimation Toward the Long Run Effects of Dynamic Panel Data Models," Economics Letters, 63, 151-158.

Rajan, Raghuram G. 2010. Fault Lines: How Hidden Fractures Still Threaten the World Economy, Princeton: Princeton University Press.

Rebelo, Sergio T. 1991. "Long-run Policy Analysis and Long-run Growth,” Journal of Political Economy, $99,500-521$.

Rice, Patricia and Anthony J. Venables. 2003. "Equilibrium Regional Disparities: Theory and British Evidence," Regional Studies, 37(6\&7), 675-686.

Rodríguez-Pose, Andrés. 2013. "Do Institutions Matter for Regional Development?," Regional Studies, 47(7), 1034-1047.

Rodríguez-Pose, Andrés and Vassilis Tselios. 2010. "Inequalities in Income and Education and Regional Economic Growth in Western Europe," Annals of Regional Science, 44, 349-375.

Rooth, Dan-Olof and Anders Stenberg. 2012. "The Shape of the Income Distribution and Economic Growth - Evidence from Swedish Labor Market Regions," Scottish Journal of Political Economy, 59(2), 196-223.

Royuela, Vicente. forthcoming. "The Role of Urbanisation on International Migrations. A Case Study of EU and ENP Countries," International Journal of Manpower.

Saint-Paul, Gilles and Thierry Verdier. 1993. "Education, Democracy and Growth," Journal of Development Economics, 42, 399-407.

Stiglitz, Joseph. 2009. "The Global Crisis, Social Protection and Jobs," International Labour Review, $148(1-2), 1-13$.

Voitchovsky, Sarah. 2005. "Does the Profile of Income Inequality Matter for Economic Growth? Distinguishing Between the Effects of Inequality in Different Parts of the Income Distribution," Journal of Economic Growth, 10(3), 273-296.

Weeks, John R., Allan G. Hill, Douglas A. Stow, Arthur Getis and Debbie Fugate. 2006. "The Impact of Neighborhood Structure on Health Inequalities in Accra, Ghana," in Population Association of America, Annual Meeting Program, 1-34.

World Bank. 2006. World Development Report 2006: Equity and Development. Washington, DC: The World Bank. 
Annex 1. Data sources for income inequality measures

\begin{tabular}{|c|c|c|c|}
\hline Country & Data source & Waves & $\begin{array}{l}\text { Number of } \\
\text { regional } \\
\text { units (TL2) } \\
\end{array}$ \\
\hline Belgium & $\begin{array}{l}\text { European Union Statistics on Income and Living } \\
\text { Conditions (EU-SILC) }\end{array}$ & $\begin{array}{l}2004,2007,2010, \\
2012\end{array}$ & 3 regions \\
\hline Canada & Survey of Labour and Income Dynamics (SLID) & $\begin{array}{l}2004,2006,2008, \\
2010\end{array}$ & 10 regions \\
\hline Chile & $\begin{array}{l}\text { Encuesta de Caracterización Socioeconómica } \\
\text { Nacional (CASEN) }\end{array}$ & $\begin{array}{l}2003,2006,2009, \\
2011\end{array}$ & 15 regions \\
\hline Czech Republic & $\begin{array}{l}\text { European Union Statistics on Income and Living } \\
\text { Conditions (EU-SILC) }\end{array}$ & $\begin{array}{l}\text { 2005, 2007, 2010, } \\
2012\end{array}$ & 8 regions \\
\hline Estonia & $\begin{array}{l}\text { European Union Statistics on Income and Living } \\
\text { Conditions (EU-SILC) }\end{array}$ & $\begin{array}{l}2004,2007,2010, \\
2012\end{array}$ & 1 region \\
\hline Finland & $\begin{array}{l}\text { European Union Statistics on Income and Living } \\
\text { Conditions (EU-SILC) }\end{array}$ & $\begin{array}{l}2004,2007,2010, \\
2012\end{array}$ & 4 regions \\
\hline France & $\begin{array}{l}\text { European Union Statistics on Income and Living } \\
\text { Conditions (EU-SILC) }\end{array}$ & $\begin{array}{l}2004,2007,2010, \\
2012\end{array}$ & 22 regions \\
\hline Greece & $\begin{array}{l}\text { European Union Statistics on Income and Living } \\
\text { Conditions (EU-SILC) }\end{array}$ & $\begin{array}{l}2004,2007,2010, \\
2012\end{array}$ & 4 regions \\
\hline Italy & Indagine sulle condizioni di vita (UDB IT SILC) & $\begin{array}{l}2004,2007,2010, \\
2012\end{array}$ & 21 regions \\
\hline Korea & Korean Labour \& Income Panel Study (KLIPS) & $2004,2006,2008$ & 6 regions \\
\hline Luxembourg & $\begin{array}{l}\text { European Union Statistics on Income and Living } \\
\text { Conditions (EU-SILC) }\end{array}$ & $\begin{array}{l}2005,2007,2010, \\
2012\end{array}$ & 1 region \\
\hline Mexico & $\begin{array}{l}\text { Encuesta Nacional de Ingreso y Gastos de los } \\
\text { Hogares (ENIGH) }\end{array}$ & $\begin{array}{l}2005,2008,2010, \\
2012\end{array}$ & 32 regions \\
\hline Spain & $\begin{array}{l}\text { European Union Statistics on Income and Living } \\
\text { Conditions (EU-SILC) }\end{array}$ & $\begin{array}{l}2004,2007,2010, \\
2012\end{array}$ & 19 regions \\
\hline $\begin{array}{l}\text { United } \\
\text { Kingdom }\end{array}$ & $\begin{array}{l}\text { European Union Statistics on Income and Living } \\
\text { Conditions (EU-SILC) }\end{array}$ & 2010,2012 & 12 regions \\
\hline United States & Current Population Survey (CPS) & $\begin{array}{l}2002-2003-2004 \\
2005-2006-2007 \\
2008-2009-2010 \\
2011-2012\end{array}$ & 51 regions \\
\hline
\end{tabular}


Annex 2. Data description

\begin{tabular}{|c|c|c|}
\hline Variable & Definition & Source \\
\hline In GDP per capita & $\begin{array}{l}\text { Log of per capita GDP in constant millions of USD PPP } \\
\text { (reference year 2005) }\end{array}$ & OECD Regional Statistics \\
\hline Gini & Gini Index of household income & $\begin{array}{l}\text { Authors' calculations based on } \\
\text { national income household } \\
\text { surveys }\end{array}$ \\
\hline p80-20 & Quintile ratio & $\begin{array}{l}\text { Authors' calculations based on } \\
\text { national income household } \\
\text { surveys }\end{array}$ \\
\hline p90-10 & Decile ratio & $\begin{array}{l}\text { Authors' calculations based on } \\
\text { national income household } \\
\text { surveys }\end{array}$ \\
\hline p90-50 & Top decile ratio & $\begin{array}{l}\text { Authors' calculations based on } \\
\text { national income household } \\
\text { surveys }\end{array}$ \\
\hline p50-10 & Bottom decile ratio & $\begin{array}{l}\text { Authors' calculations based on } \\
\text { national income household } \\
\text { surveys }\end{array}$ \\
\hline pov40 & Poverty: poverty line at $40 \%$ of national median income & $\begin{array}{l}\text { Authors' calculations based on } \\
\text { national income household } \\
\text { surveys }\end{array}$ \\
\hline pov60 & Poverty: poverty line at $60 \%$ of national median income & OECD Regional Statistics \\
\hline Urbanisation & $\begin{array}{l}\text { Share of regional population living in OECD functional } \\
\text { urban areas (FUA) }\end{array}$ & $\begin{array}{l}\text { OECD Regional and } \\
\text { Metropolitan Statistics (OECD, } \\
\text { 2012) }\end{array}$ \\
\hline Total population & Total regional population $(\log )$ & OECD Regional Statistics \\
\hline Religion diversity & $\begin{array}{l}\text { Inverse of Herfindahl Index on the shares of different } \\
\text { religions (no sub-aggregates) }\end{array}$ & World Religion Dataset, ATLA \\
\hline $\begin{array}{l}\text { Share of the most popular } \\
\text { religion }\end{array}$ & $\begin{array}{l}\text { Share of the most popular religion (no sub-aggregates } \\
\text { considered) }\end{array}$ & World Religion Dataset, ATLA \\
\hline Agriculture share & $\begin{array}{l}\text { Share of gross value added (GVA) in agriculture, forestry } \\
\text { and fishing over total GVA }\end{array}$ & OECD Regional Statistics \\
\hline Industry share & Share of GVA in industry, including energy, over total GVA & OECD Regional Statistics \\
\hline Construction share & Share of GVA in construction over total GVA & OECD Regional Statistics \\
\hline Education share in low levels & $\begin{array}{l}\text { Share of the labour force in lower education levels }(0-2 \\
\text { ISCED groups) }\end{array}$ & OECD Regional Statistics \\
\hline $\begin{array}{l}\text { Education share in average } \\
\text { levels }\end{array}$ & $\begin{array}{l}\text { Share of the labour force in middle education levels (3-4 } \\
\text { ISCED groups) }\end{array}$ & OECD Regional Statistics \\
\hline $\begin{array}{l}\text { Education share in high } \\
\text { levels }\end{array}$ & $\begin{array}{l}\text { Share of the labour force in higher education levels (5-6 } \\
\text { ISCED groups) }\end{array}$ & OECD Regional Statistics \\
\hline Elderly rate & $\begin{array}{l}\text { Elderly rate (ratio between people aged } 65 \text { years or more } \\
\text { and people aged } 15-64 \text { years), expressed in percentage }\end{array}$ & OECD Regional Statistics \\
\hline Unemployment rate & Proportion of unemployed people over total labour force & OECD Regional Statistics \\
\hline $\begin{array}{l}\text { Labour force participation } \\
\text { rate }\end{array}$ & $\begin{array}{l}\text { Participation rate (labour force divided by the working-age } \\
\text { population } 15-64 \text { years old), expressed in percentage }\end{array}$ & OECD Regional Statistics \\
\hline Voters & $\begin{array}{l}\text { Percentage of registered voters who voted during general } \\
\text { elections }\end{array}$ & OECD Regional Statistics \\
\hline Murder rate & Ratio of total murders over 100,000 people & OECD Regional Statistics \\
\hline
\end{tabular}


Annex 3. Inequality and GDP per capita growth rates, according to different indicators of inequality
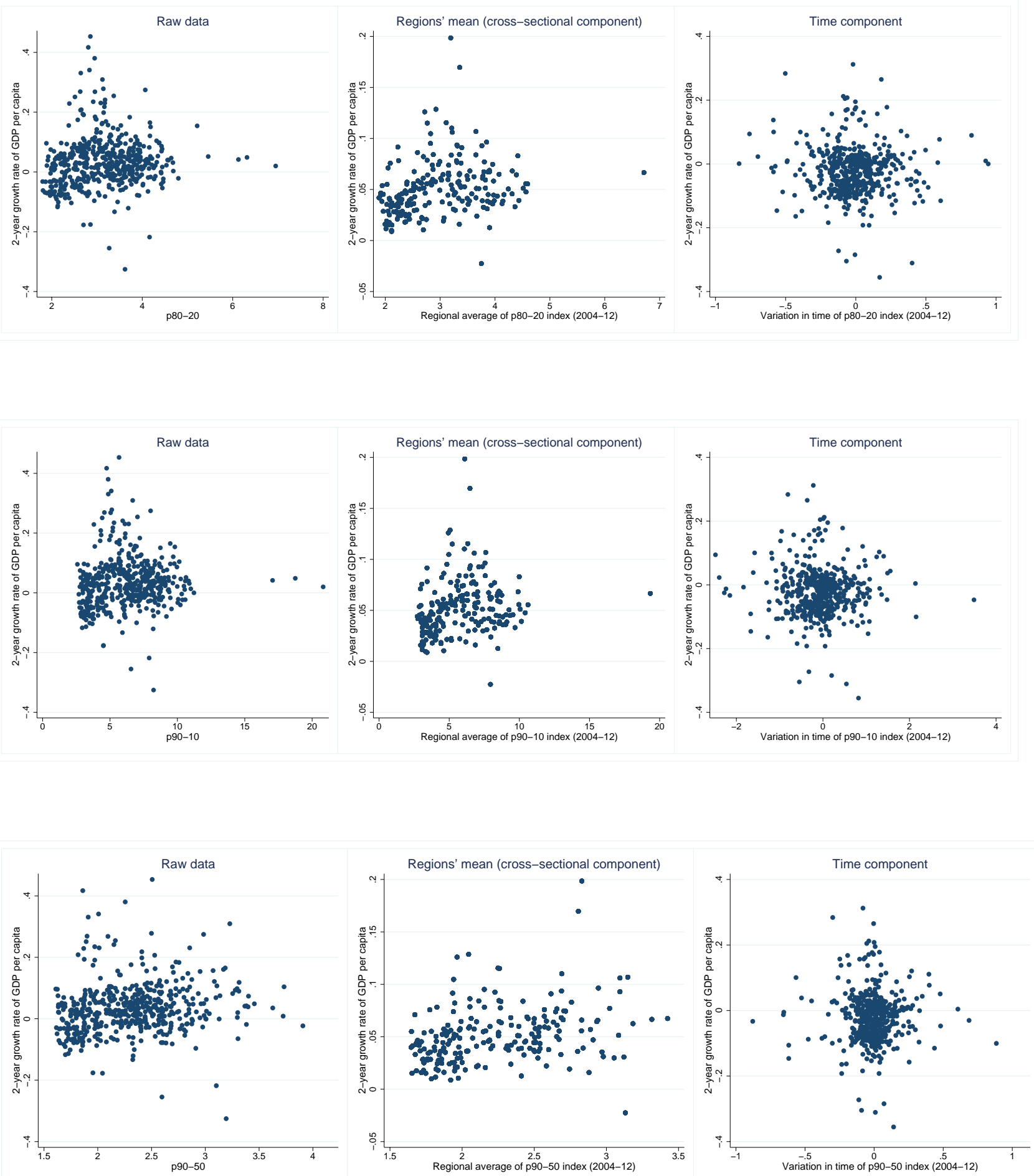

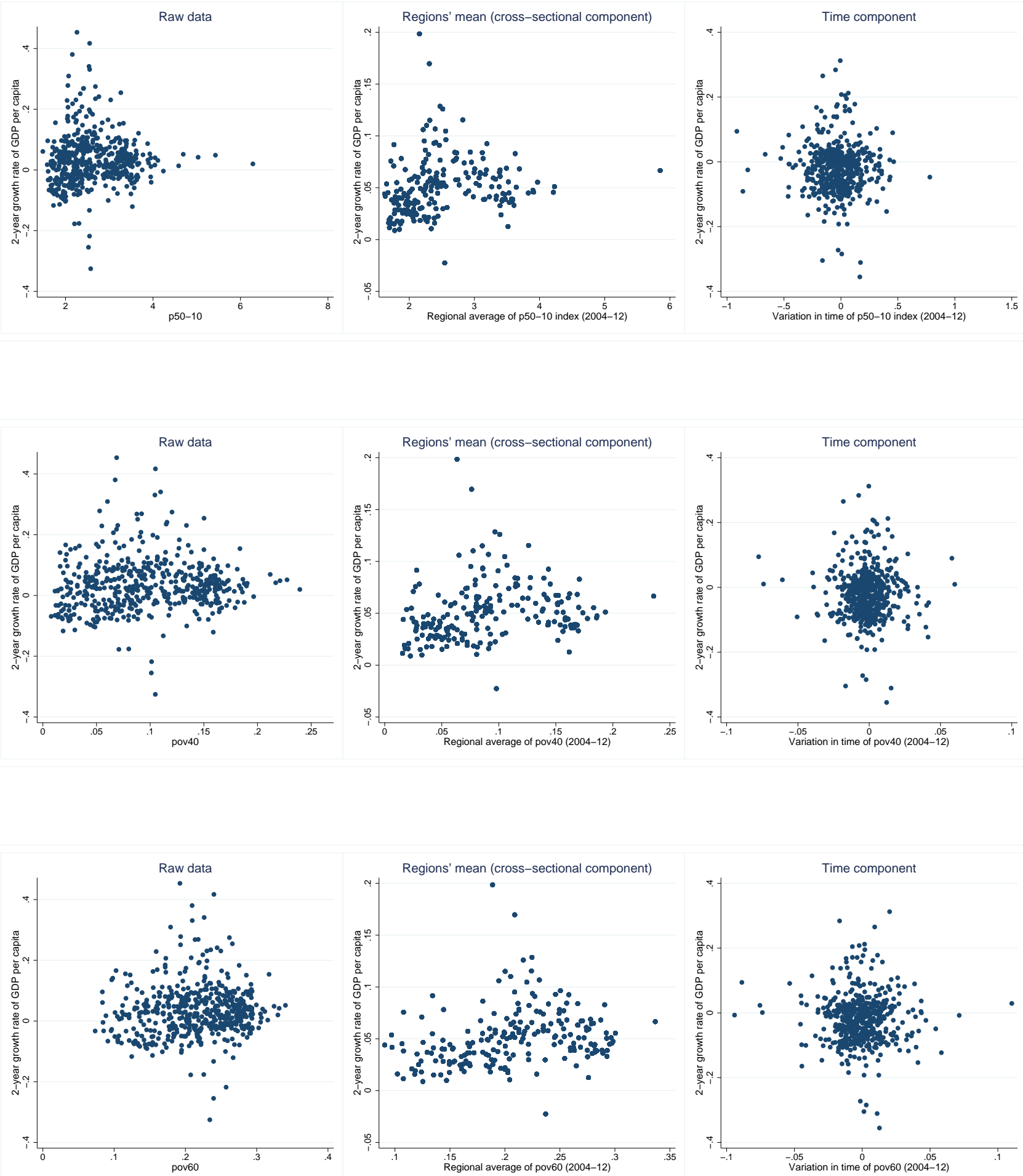